


\section{Cirkulær guide}

Fællesnordisk vejledning til udvikling af "den cirkulære kommune" i Norden

Anders Christiansen, Mette Skovbjerg, Bjørn Baver og Kia Rose Egebæk

TemaNord 2019:511 


\section{Cirkulær guide}

Fællesnordisk vejledning til udvikling af "den cirkulære kommune" i Norden

Anders Christiansen, Mette Skovbjerg, Bjørn Baver og Kia Rose Egebæk

ISBN 978-92-893-6025-8 (PRINT)

ISBN 978-92-893-6026-5 (PDF)

ISBN 978-92-893-6027-2 (EPUB)

http://dx.doi.org/10.6027/TN2019-511

TemaNord 2019:511

ISSN 0908-6692

Standard: PDF/UA-1

ISO 14289-1

(c) Nordic Council of Ministers 2019

Omslagsfoto: Unsplash.com

\section{Ansvarsfraskrivelse}

Denne publikation er finansieret af Nordisk Ministerråd. Indholdet afspejler dog ikke nødvendigvis Nordisk Ministerråds synspunkter, holdninger, anskuelser eller anbefalinger.

\section{Rettigheder og tilladelser}

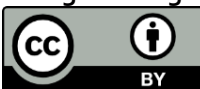

Dette værk er gjort tilgængeligt i henhold til Creative Commons Attribution 4.0 International License (CC BY 4.0) https://creativecommons.org/licenses/by/4.0

Oversættelser: Hvis du oversætter dette værk, bedes du inkludere følgende ansvarsfraskrivelse: Denne oversættelse er ikke produceret af Nordisk Ministerråd og skal ikke betragtes som officiel. Nordisk Ministerråd kan ikke drages til ansvar for oversættelsen eller eventuelle fejl, den måtte indeholde.

Bearbejdning: Hvis du bearbejder dette værk, bedes du inkludere følgende ansvarsfraskrivelse sammen med tilskrivelsen af værket: Dette er en bearbejdning af et originalt værk publiceret af Nordisk Ministerråd. Ansvaret for de synspunkter og holdninger, der kommer til udtryk i bearbejdelsen, påhviler udelukkende forfatteren/forfatterne til bearbejdningen. Synspunkter og holdninger i denne bearbejdning er ikke godkendt af Nordisk Ministerråd. 
Tredjepartsindhold: Nordisk Ministerråd er ikke nødvendigvis ejer af samtlige dele af dette værk. Nordisk Ministerråd kan derfor ikke garantere, at genbrug af tredjepartsindhold ikke udgør en overtrædelse af en tredjeparts ophavsret. Hvis du ønsker at genbruge tredjepartsindhold, bærer du selv ansvaret for enhver overtrædelse af ophavsretten. Du er ansvarlig for at vurdere, om det er nødvendigt at indhente en tilladelse til anvendelse af tredjepartsindhold og i så fald at indhente den nødvendige tilladelse fra ophavsretsindehaveren. Eksempler på tredjepartsindhold inkluderer, men er ikke begrænset til, tabeller, illustrationer og billeder.

Fotorettigheder (genbrug kræver yderligere tilladelse):

Alle henvendelser vedrørende rettigheder og licenser skal stiles til:

Nordisk Ministerråd/PUB

Ved Stranden 18

1061 København K

Telefonnr. 33960200

pub@norden.org

Det nordiske samarbejde

Det nordiske samarbejde er en af verdens mest omfattende regionale samarbejdsformer. Samarbejdet omfatter Danmark, Finland, Island, Norge og Sverige samt Færøerne, Grønland og Åland.

Det nordiske samarbejde er både politisk, økonomisk og kulturelt forankret, og er en vigtig medspiller i det europæiske og internationale samarbejde. Det nordiske fællesskab arbejder for et stærkt Norden i et stærkt Europa.

Det nordiske samarbejde ønsker at styrke nordiske og regionale interesser og værdier i en global omverden. Fælles værdier landene imellem er med til at styrke Nordens position som en af verdens mest innovative og konkurrencedygtige regioner.

\section{Nordisk Ministerråd}

Nordens Hus

Ved Stranden 18

1061 København K

www.norden.org

Download nordiske publikationer: www.norden.org/nordpub 



\section{Indhold}

Forord

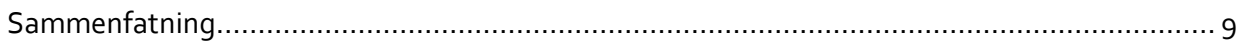

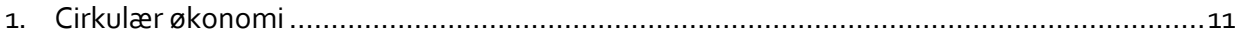

Definition og introduktion af cirkulær økonomi ...................................................... 11

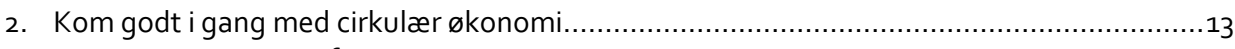

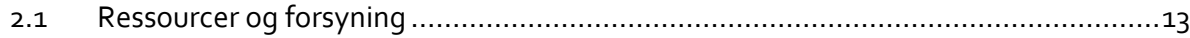

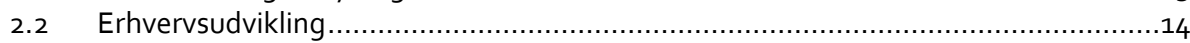

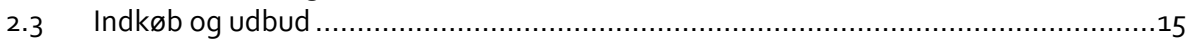

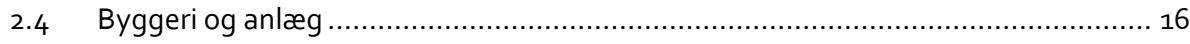

3. De nordiske kommuner og kommuneforeninger ................................................ 17

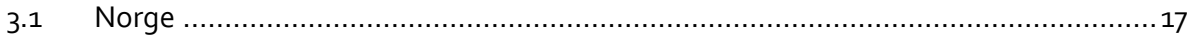

3.2 Danmark

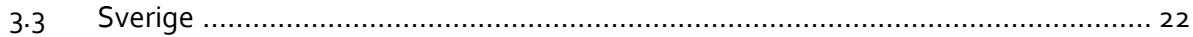

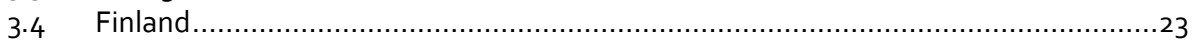

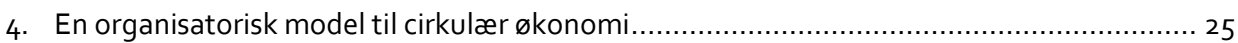

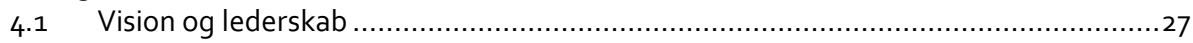

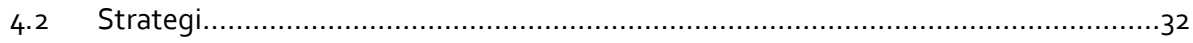

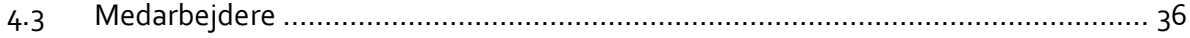

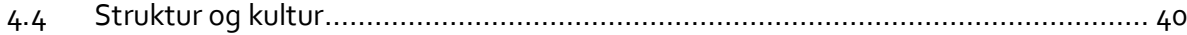

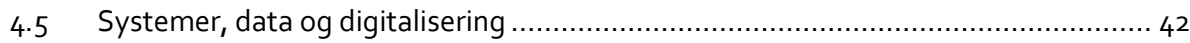

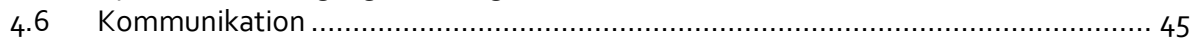

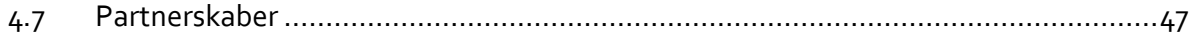

5. Nordiske eksempler på cirkulær økonomi i kommuner ............................................ 49

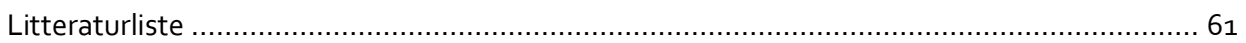

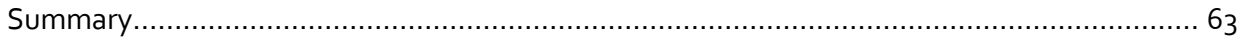




\section{Forord}

Cirkulær økonomi står højt på dagsordenen i både EU og de nordiske lande og ses som en del af svaret på mange af de omfattende udfordringer, vores samfund står over for. Vores lineære måde at producere og forbruge på er ikke bæredygtig - ikke engang på kort sigt. Vi har kun en begrænset mængde ressourcer til rådighed, og mange værdifulde ressourcer går tabt. Cirkulær økonomi kan medvirke til en global bæredygtig omstilling, som passer direkte ind i FN's 17 Verdensmål, og som både lande, kommuner og virksomheder kan arbejde hen mod i fællesskab.

Kommunerne har en helt central rolle $\mathrm{i}$ at understøtte den cirkulære omstilling, både som bindeled mellem borgere og markedet, som myndighed og i partnerskaber med borgerne og virksomhederne. Kommunerne kan anvende deres indkøbspolitik til at skabe innovation, øget genanvendelse og recirkulering gennem cirkulære grønne indkøbsmodeller og i udbud af bygge- og renoveringsopgaver. Samtidig kan kommunerne drive og understøtte en lokalt forankret omstilling, så virksomheder får drejet deres forretningsmodeller og investeringer i en mere cirkulær retning.

Cirkulær økonomi i kommunen handler om en kredsløbsfokuseret grøn omstilling på tværs af forvaltninger og i alle kommunens aktiviteter. Igennem planlægning, myndighedsopgaver, indkøb, udbud og erhvervsfremmeindsatser kan kommunen accelerere den cirkulære omstilling i erhvervslivet og i services til borgerne.

Kommuner i Norden har mange fællestræk i relation til forvaltnings- og ressortområder, og den politiske opbygning og kulturen er relativt ens. De nordiske kommuner har i forvejen god tradition for at samarbejde og lære af hinandens erfaringer, og dette er der også rig mulighed for i relation til den cirkulære økonomi, som mange opfatter som vanskelig at "tage fat på". Cirkulær økonomi er en god mulighed for kommunerne til at skabe nye typer af erhverv, styrke innovationskraften og skabe gode arbejdspladser, og der er åbenlyse muligheder for at udnytte de gode erfaringer og skabe læring på tværs af Norden.

Formålet med denne vejledning er at styrke det nordiske samarbejde kommunerne imellem med implementering af cirkulær økonomi gennem formulering af en fællesnordisk metodik til udvikling af "den cirkulære kommune". Vejledningen skal medvirke til at give fælles grundlag, sprog og metoder at arbejde og samarbejde ud fra og sigter på at skabe et fælles grundlag til at adressere cirkulær økonomi ud fra et organisatorisk perspektiv. Samtidig sigter vejledningen på at facilitere videndeling på tværs af Norden ved at samle eksisterende erfaringer med cirkulær økonomi i kommunerne til fælles læring og inspiration.

Kommunernes Landsforening i Danmark (KL) og PlanMiljø har udarbejdet vejledningen med støtte fra Nordisk Ministerråd og med input fra en lang række kommuner over hele Norden - til hvilke der hermed rettes en tak. 


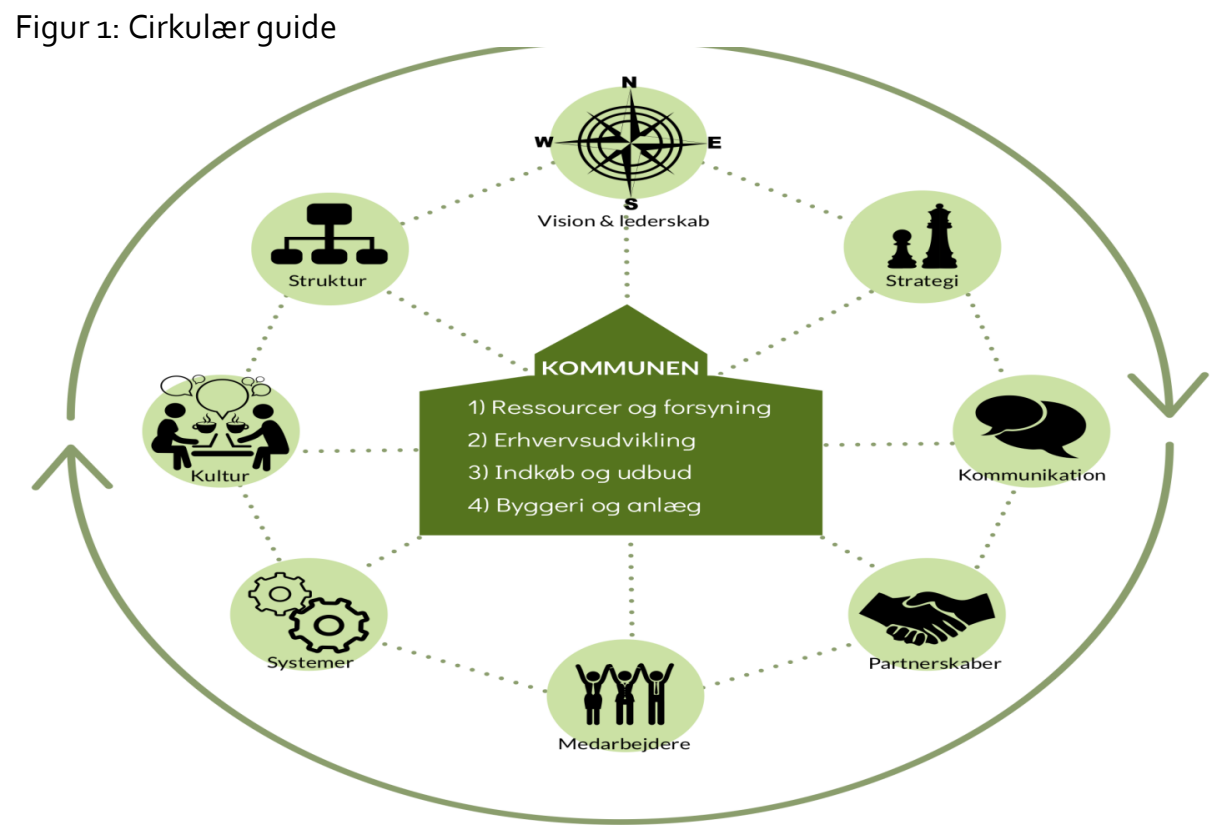

En fællesnordisk vejledning til udvikling af "den cirkulære Kommune" i Norden. 


\section{Sammenfatning}

Cirkulær økonomi i kommunen handler om en kredsløbsfokuseret grøn omstilling på tværs af forvaltninger og i alle kommunens aktiviteter. Igennem planlægning, myndighedsopgaver, indkøb, udbud og erhvervsfremmeindsatser kan kommunen accelerere den cirkulære omstilling i erhvervslivet og i services til borgerne. Denne vejledning opsamler og formidler erfaringer og metoder på cirkulære initiativer fra kommuner over hele Norden, så indsatsen kan blive endnu mere dynamisk og effektfuld.

De nordiske kommuneforeninger understøtter på forskellig vis cirkulær økonomi i kommunerne gennem dialog, videndelings- og netværksaktiviteter. Dertil samarbejder kommuneforeningerne og de statslige myndigheder i de enkelte lande, hvor ikke mindst Finland er langt fremme med et organiseret og formaliseret samarbejde.

Der er en stor variation i, hvor langt de enkelte kommuner er kommet i arbejdet med at omstille til en mere cirkulær kommune. Der findes et utal af eksempler på cirkulære tiltag - fra små konkrete projekter til store tværkommunale helhedsvisioner - og der opnås gevinster inden for alle tre bæredygtighedsdimensioner: miljø, økonomi og sociale forhold. Gennemgangen af de nordiske kommuners indsatser inden for cirkulær økonomi viser, at der særligt er innovative aktiviteter inden for fire forvaltningsområder:

- Ressourcer og forsyning

- Erhvervsudvikling

- Indkøb og udbud

- Byggeri og anlæg

De fire temaer og tre bæredygtighedsdimensioner er alle lige legitime, idet valget af indsatsfelt afhænger af den konkrete kommunale kontekst - men naturligt nok står den miljømæssige dimension tydeligt i alle de kommunale cases. Den økonomiske dimension ses mest udpræget i temaerne erhvervsudvikling og indkøb og udbud, forstået som øget omsætning, nye markeder og sparede omkostninger. Den sociale dimension-forstået som socialøkonomiske arbejdspladser, samskabelse, borgerinddragelse m.m. indgår også tydeligt de undersøgte cases, der for eksempel omfatter undervisningsaktiviteter, borgernære miljøindsatser og socialøkonomiske arbejdspladser på affaldsområdet.

I mange cases er kommunerne initiativtager og fødselshjælper til cirkulære indsatser, idet kommunerne kan tage en omkostning på kort sigt for at sikre bedre miljø og lavere omkostninger for borgerne og virksomheder på længere sigt - kommunerne forbereder det cirkulære marked. Det gælder for eksempel udvikling af nye forretningsmodeller på affalds- eller spildevandsområderne, hvorved der også er skabt cirkulære arbejdspladser $\mathrm{i}$ kommunen. 
Kortlægningen af de nordiske kommuners arbejde med cirkulær økonomi er baseret på en organisatorisk ramme, der har styrket forståelsen af, hvordan den kommunale organisatoriske opbygning muliggør udviklingen og implementeringen af nye cirkulære projekter. Der er kommunerne imellem stor forskel på væsentligheden af de forskellige elementer, og indsatser inden for hvert af de organisatoriske elementer kan understøtte den gradvise omstilling til cirkulær økonomi, men alle elementer skal i spil, hvis cirkulær økonomi for alvor skal forankres $\mathrm{i}$ kommunen:

- En overordnet vision for cirkulær økonomi i kommunen og tydeligt lederskab fra kommunens politiske og administrative top.

- En strategi for cirkulær økonomi i kommunen og en klar plan for det pågældende projekt.

- Rigtige kvalifikationer hos medarbejderne til indsatsen og tydeligt engagement og ejerskabsfølelse hos både medarbejdere og interessenter.

- En kommunal kultur og struktur, der understøtter den brede cirkulær økonomiindsats og de konkrete projekter.

- Velfungerende systemer til at understøtte cirkulær økonomi projekter.

- Midler og kanaler til effektiv kommunikation.

- Indgåelse af gode og brede partnerskaber til at gennemføre indsatserne. 


\section{Cirkulær økonomi}

Cirkulær økonomi handler grundlæggende om at få mest mulig værdi ud af produkter og materialer og holde ressourcerne i kredsløb længst muligt. Det kan ske ved at forlænge produkters levetid, designe med sigte på genbrug og genanvendelse, undgå affald og helt konkret spare på vand og omstille til vedvarende energi. Cirkulær økonomi bryder med den traditionelle lineære værdikæde, hvor ressourcer hurtigt ender som affald, og åbner i stedet op for muligheden for, at ressourcer, affalds- og materialestrømme kan gå tilbage i værdikæden for at indgå i produktionen igen eller som input i et helt nyt kredsløb.

Cirkulær økonomi omfatter også nytænkende forretningsmodeller, hvor forbrugere kan returnere produkter til reparation eller opgradering, og hvor borgere, virksomheder, kommunale institutioner og forsyninger etc. kan lease produkter i stedet for at sælge dem - igen for at få mest muligt ud af produkterne og reducere det samlede ressourceforbrug i alle led i værdikæderne.

Overgangen til en cirkulær økonomi er en fantastisk mulighed for at omdanne vores økonomi og gøre den mere bæredygtig, bidrage til klimamålene og bevarelsen af verdens ressourcer, skabe lokale arbejdspladser og skabe konkurrencemæssige fordele for Europa i en verden, der undergår gennemgribende forandringer ${ }^{1}$. Videre fastslås det: Overgangen til en cirkulær $ø$ konomi vil også bidrage til at opfylde målene for 2030-dagsordenen for bæredygtig udvikling. ${ }^{1}$

Europa Kommissionen 2018

\section{Definition og introduktion af cirkulær økonomi}

I EU's handlingsplan for den cirkulære økonomi² er en cirkulær økonomi beskrevet som en økonomi, hvor værdien af produkter, materialer og ressourcer bevares i økonomien længst muligt, og affaldsproduktionen minimeres.

Deling og effektiv brug af ressourcer er tæt forbundet med den grundlæggende begrundelse for offentlige / kommunale tjenester: uddannelse, biblioteker, offentlig transport og tekniske tjenester til vand, affald, energi mv. Den cirkulære økonomi er

\footnotetext{
${ }^{1}$ COM(2018) 29. Meddelelse fra Kommissionen til Europa-parlamentet, Rådet, Det Europæiske Økonomiske og Sociale Udvalg og Regionsudvalget om en overvågningsramme for den cirkulære økonomi https://eur-lex.europa.eu/LexUriServ/LexUriServ.do?uri=COM:2018:0029:FIN:DA:PDF

${ }^{2} \operatorname{COM}$ (2015) 614. Closing the loop - An EU action plan for the Circular Economy
} 
ikke nødvendigvis noget nyt, idet de forskellige elementer er kendt under konkrete betegnelser som ressourcebevidsthed, langsigtede investeringer, genbrug, vugge til vugge og bæredygtigt design. Men det samlende begreb "cirkulær økonomi" sætter et nyt og nødvendigt fokus på at øge ressourcernes anvendelighed og værdier, samtidig med at affald og miljøforringelse minimeres. En væsentlig faktor for konceptets appel til kommuner er dets kombination af højteknologi (IT, digitalisering, innovation) og lavteknologi (reparation, deling, involvering) med klar mulighed for social integration ${ }^{3}$.

Kommunerne har derfor en afgørende rolle i omstillingen til en mere cirkulær økonomi. I de nordiske lande har kommunerne ansvaret for langt hovedparten af de borgernære serviceopgaver, og med en andel på over 50 procent af det offentlige forbrug (DK) har udviklingen i den kommunale økonomi også en afgørende betydning for den samlede omstilling til større bæredygtighed. Kommunerne sikrer de konkrete rammebetingelser for cirkulære løsninger, og så kan de anvende deres økonomiske råderum til at skabe innovation og nytænkning. Når kommunen arbejder cirkulært, danner den bindeled mellem borgerne og markedet, hvor ressourcer og produkter føres op i kredsløbene via vedligeholdelse, genbrug, istandsættelse og genanvendelsesaktiviteter. På den måde er kommunen både vigtig for rammesætningen, for omstillingen til mere genanvendelse af borgernes affald og i skabelsen af cirkulære vækstvirksomheder.

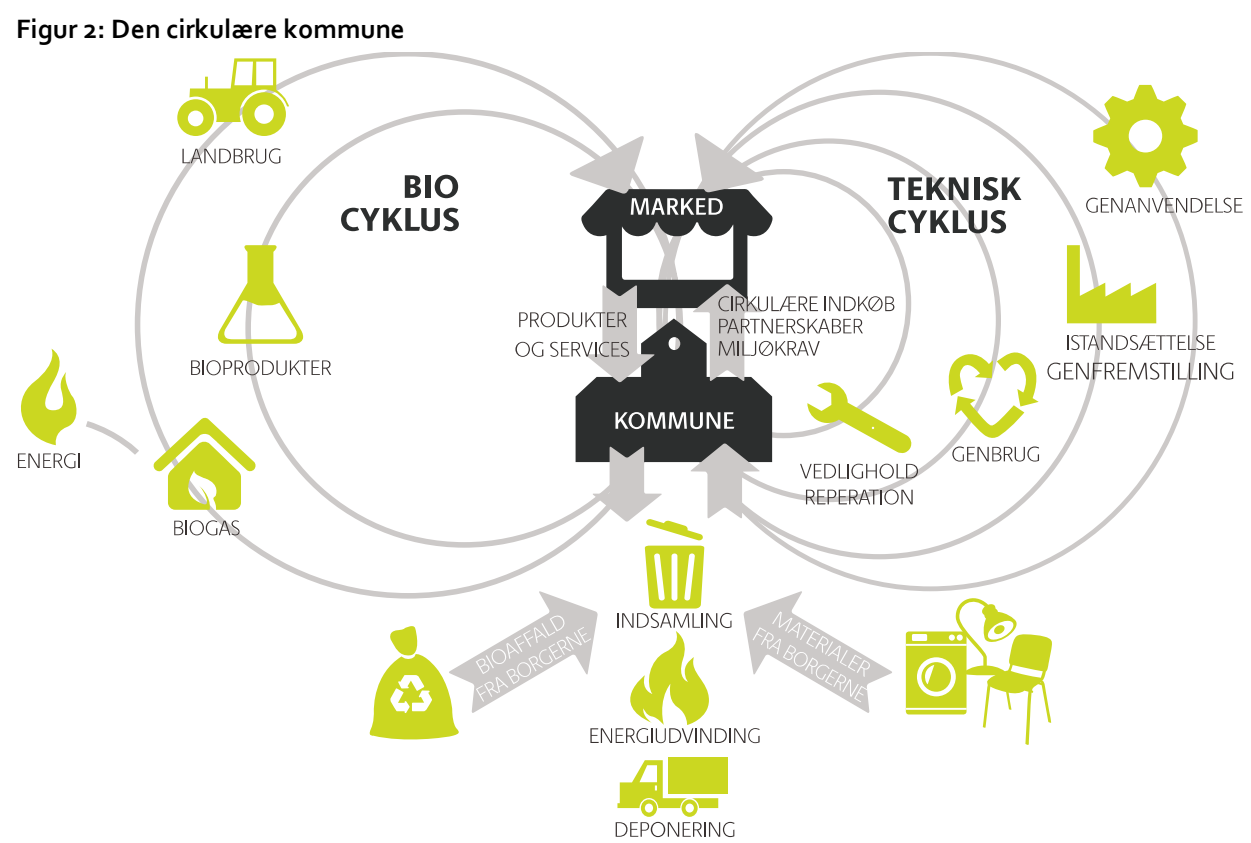

3 Mere information om EU's arbejde med cirkulær økonomi kan findes på http://ec.europa.eu/environment/circular-economy/index_en.htm 


\section{Kom godt i gang med cirkulær økonomi}

Arbejdet med cirkulær økonomi i kommunen handler om bæredygtig grøn omstilling i alle forvaltninger og om samarbejde med erhvervsliv, borgere og uddannelsesinstitutioner. Det handler om at tænke i værdikæder, og en dedikeret indsats for cirkulær økonomi vil inddrage og påvirke en lang række indsatsområder og interessenter i kommunen. Baseret på de nordiske erfaringer kan der peges på følgende overordnede indsatsområder:

\subsection{Ressourcer og forsyning}

Fremadrettet skal man i langt højere grad betragte affald som en potentiel ressource, og vejen dertil fordrer, at affaldet forvaltes med formålet om at recirkulere mest muligt. Her er kommunerne oplagte forvaltere, idet de kan sikre udvikling også for affaldsfraktioner, der endnu ikke har kommerciel værdi.

Med udgangspunkt i affaldshierarkiet kan kommunen arbejde på at fremme affaldsforebyggelse, genbrug og genanvendelse, og der er talrige eksempler Norden over på, hvordan der arbejdes med hele værdikæder:

- Ressourcebesparelser og forebyggelse af affald via information; bl.a. har Borgå Kommune (Fl) arbejdet med at sætte fokus på ressourcebevidsthed hos børn og familier gennem et miljøpas, hvor skoleleverne skal notere deres miljøvenlige

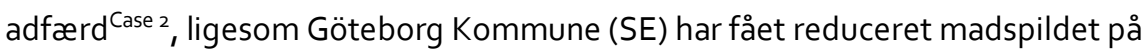
plejehjemmet Sekelbo med 23 procent og restaffaldet med 10 procent samt skånet miljøet for seks tons $\mathrm{CO}_{2}$ gennem aktiv inddragelse af plejehjemmets personale ${ }^{\text {Case } 8}$.

- Nye genbrugs-og reparationsløsninger; for eksempel har Randers Kommune (DK) været med til at starte den socialøkonomiske virksomhed GOGGS, der skaber rummelige arbejdspladser for medborgere med nedsat erhvervsevne og samtidig øger mængden af genbrug. Målet er, at affaldsmængden skal nedbringes med op mod 100 tons årligt, og GOGGS vil på sigt beskæftige 75 medarbejdere Case $15^{\text {. }}$

- Udvikling af genanvendelsesløsninger i samarbejder med erhvervslivet og vidensinstitutioner; for eksempel har Steinkjer Kommune (NO) og en række interkommunale affaldsselskaber i Norge etableret samarbejdet "SeSammen", der har resulteret i et nyt anlæg ("Ecopro") for omdannelse af biologisk affald. Derudover er målet med samarbejdet at udføre en samfundsansvarlig kredsløbsbaseret ressourceudnyttelse, som lever op til affaldshierarkiet ${ }^{\text {Case } 14}$. 
Kommunen kan også igangsætte forsøgsordninger, hvor virksomheder og private får mulighed for at trække materialer ud af affaldsstrømmen. Kommunen eller affaldsselskabet kan for eksempel indsamle og/eller sortere specifikt til virksomheder, der kan genanvende ressourcerne og finansiere de forholdsmæssige omkostninger. Herigennem kan efterspørgslen udvikles. Derefter kan affaldsfraktionen indsamles og udbydes frit på markedet - præcis som det sker med andre affaldsfraktioner, der allerede handles på det internationale marked. Bl.a. har Asker Kommune (NO) udviklet et system for indsamling af tekstiler til genbrug hos private aktører med både miljømæssige og socialøkonomiske fordele Case 24, og Nordland fylkekommune (NO) har sammen med en række private aktører i 2008 etableret et landsomfattende system for indsamling af kasseret fiskemateriale og har siden 2012 udvidet dette til også at omfatte materiale fra andre dele af Europa ${ }^{\text {Case } 28 .}$.

\subsection{Erhvervsudvikling}

De fleste kommuner har udarbejdet en erhvervsstrategi, der skal bidrage til vækst i erhvervslivet og sikre et godt lokalt erhvervsklima i kommunen. Cirkulær økonomi kan udgøre en central platform for innovation, hvor forretningsudvikling og vækst baseres på en forståelse af de cirkulære muligheder for at holde ressourcerne længst muligt i spil. Ved at omstille til en cirkulær forretningsmodel kan virksomhederne spare penge på råstoffer, skabe lokale arbejdspladser, styrke eksporten og bruge bæredygtighed som konkurrenceparameter. Kommunen kan bl.a.:

- Facilitere netværk og inspirere særligt mindre og mellemstore virksomheder til udvikling af cirkulære forretningsmodeller. De danske kommuner Lejre, Gladsaxe, Hvidovre, Rødovre og Københavns Kommune har indgået samarbejder med et mindre trykkeri-firma, der gennem samarbejde, investeringer og kommunal støtte i dag tilbyder 100 procent giftfrie og 100 procent biologisk nedbrydelige tryksager og emballage ${ }^{\text {Case } 26}$. Industriklyngen i MO i Rana Kommune (NO) har givet de involverede virksomheder mulighed for at udnytte hinandens restprodukter, hvilket fører til en betydelig reducering i forbruget af energi og andre ressourcer. Industriklynger er en vigtig udviklingsmulighed for kommunernes arbejde med cirkulær økonomi ${ }^{\text {Case } 25 .}$

- Skabe kontakt og indsamle viden om omstillingsparate virksomheder gennem bl.a. tilsynsarbejdet, hvilket en række kommuner, herunder for eksempel Gladsaxe (DK), praktiserer.

- Styrke cirkulær økonomi på tværs af virksomheder gennem for eksempel tilskudsordninger, pilotprojekter, offentlig/private samarbejder og industrielle symbioser. For eksempel har de danske kommuner Holbæk, Slagelse, Odsherred, Køge, Kalundborg og Guldborgsund fra 2014-2017 tilbudt virksomheder en gennemgang af deres respektive ressourceanvendelse og støtte til udvikling af nye og grønnere forretningsmodeller i projektet "Fra Rest til Ressource", der 
forventer at give energibesparelser på ca. $33.000 \mathrm{GJ} / a ̊$, materialebesparelse på ca. 1 ton/år og en $\mathrm{CO}_{2}$-reduktion på ca. $14.000 \mathrm{CO}_{2} /$ år Case 23.

\subsection{Indkøb og udbud}

De nordiske kommuner indkøber hvert år produkter og services for milliardbeløb. Kommunernes indkøb er en oplagt mulighed for at fremme cirkulær økonomi, og der er allerede gjort erfaringer med "cirkulære indkøb" i bl.a. Danmark og Sverige. Gennem de cirkulære indkøb kan kommunen sikre en bæredygtig anvendelse af egne ressourcer samtidig med, at kommunen er med til at fremme markedet for cirkulære produkter og services. Kommunen kan arbejde med cirkulært indkøb og udbud på flere måder:

- Øget efterspørgsel efter genbrug og højkvalitetsprodukter med lange levetider og mulighed for genbrug og reparation. Aalborg Kommune (DK) har gennemført et udbud, hvor eksisterende møbler genanvendes, repareres og tænkes ind i nye læringsmiljøer på skoler ${ }^{\text {Case } 31}$. Växjö Kommune (SE) har udarbejdet konceptet Möbelcirkeln, hvor kommunale myndigheder og virksomheder kan indlevere brugte møbler til reparation og istandsættelse, hvorefter de bliver solgt via en online platform. Herigennem kan kommunens forvaltninger købe de tilgængelige møbler med både miljømæssige og økonomiske besparelser Case 37.

- Efterspørge produkter i andre forretningsmodeller som leasing, "produkt som service" og take-back-ordninger. Fokus på lange levetider og fastholdelse af ressourcer i kredsløbene kan indarbejdes i ejer- og kontraktforholdet, så der leveres gennem leasingaftaler eller "produkt som en service", hvorved ansvaret og incitamentet - for den lange levetid overgår til leverandøren. Resultatet kan være besparelser og indtægter for både kommune og leverandør - og naturligvis et mindre miljøaftryk. Sønderborg Kommune (DK) er en ud af flere kommuner, som både opnår $\mathrm{CO}_{2}$ besparelser og økonomisk gevinst gennem et take-back samarbejde med en genbrugs IT-virksomhed. Omkring 95-97 procent af det udtjente IT-udstyr kommer tilbage til markedet som genbrugt IT, i stedet for at det direkte håndteres som affald ${ }^{\text {Case }}{ }^{6}$.

I udbud må kommunen indtænke, hvordan et produkts brugsperiode kan forlænges, om der kan indarbejdes reparationsaftaler, og om det kan sikres, at produktets materialer genanvendes efter endt brug. Tankegangen i cirkulære indkøb får indflydelse på hele produktets livscyklus, og det giver et godt samspil med principperne bag totalomkostningsberegninger, som mange kommuner allerede i dag indarbejder i deres udbudsforretning. Her går samfundsøkonomi, cirkulær økonomi, produktkvalitet og service hånd i hånd.

At bevæge sig ud i cirkulære indkøb handler i høj grad om at turde afprøve nye metoder og principper i udbuddene. Det kræver, at udbudsjurister og indkøbere får mandat til at teste og måske lave fejl undervejs; her er ledelsesopbakning derfor afgørende for resultatet. 


\subsection{Byggeriog anlæg}

Kommunerne er store bygherrer inden for områder som skoler, plejehjem, veje, parker og rådhuse, og byggeri og anlæg står for en meget stor del af den ressourcemængde, som kommunerne har indflydelse på via bevidste cirkulære strategier:

- På byggeområdet handler det først og fremmest om at efterspørge lang levetid. Det bygger på kompetent lokalplanlægning, høj kvalitet og gode materialer, men også på forhold som for eksempel bygningers fleksibilitet, som gør det muligt at ændre anvendelse med en begrænset indsats. Anvendelsen af kemiske og/eller sammensatte materialer og stoffer skal begrænses, og der bør med bygningerne medfølge optegnelser over, hvor i bygningen hvilke materialer er anvendt. Malmø Kommune (SE) har foretaget et omfattende tiltag for at sikre ressourceeffektive strukturer for transport, energi og jord i den nye bydel Hyllie Case 19.

- Med sigte på at kunne genbruge eller genanvende ressourcerne kan kommunen sikre fraktionsopdelt opsamling af byggematerialer fra egne byggerier, renoveringer og nedrivninger og på den måde bidrage til at styrke hele sektoren for genbrug og genanvendelse. Data om nedrivningsmodne bygninger kan anvendes til at skabe markedsopmærksomhed og afsætning, og genbrugs- og genanvendelsesmuligheder kan parres med naboprojekter og evt. nabokommuner. Nyere eksempler viser, at den samlede økonomi ved sådanne indsatser tit er neutral eller ligefrem giver sorte tal på bundlinjen For eksempel case 16, 18, 22.

- Kommunen kan også stille krav og gå i dialog ved de mindre entrepriser, der hver dag bliver udført hos dem. Kommunen kan styrke praksis i forhold til kvalitet, brug af genanvendelige materialer, grønne produkter og byggeelementer, sikring af fremtidige muligheder for reparation, plan for sortering på pladsen samt nyttiggørelse og genbrug af materialer og affald. Både når der renoveres og bygges nyt, kan der arbejdes med totalomkostningsprincipperne, hvor også nedrivningsfasen medregnes. I Holbæk Kommune (DK) opnåede man store besparelser og høje genbrugs- og genanvendelsesprocenter ( 97,5 procent) ved gennem en grundig forundersøgelse og et tæt samarbejde med entreprenøren at fokusere på ressourceudnyttelsen ved nedrivning af en gammel skole ${ }^{\text {Case } 17}$.

Kommunen kan tage ejerskab over ressourcerne i renoverings- og nedrivningsprojekter, i stedet for at lade entreprenører om det, og hermed få rådgiverne til at tage stilling til, hvor materialerne skal hen med henblik på at genbruge og genanvende mest muligt. 


\section{De nordiske kommuner og kommuneforeninger}

I det følgende beskrives kortfattet aktiviteter indenfor cirkulær økonomi i Norge, Danmark, Sverige og Finland i de nordiske kommuneforeninger: KS i Norge, KL i Danmark, SKL i Sverige og Kuntaliitto i Finland samt statslige initiativer i de fire lande.

Afsnittet er udformet efter dialog med de respektive kommuneforeninger og giver viden og status for de enkelte landes tiltag om cirkulær økonomi på statsligt og kommuneforeningsniveau.

Sammenfattende kan det konstateres, at alle kommuneforeningerne arbejder med at understøtte implementering af den cirkulære økonomi i kommunerne. Dette sker på forskellig vis gennem dialog, videndelings- og netværksaktiviteter med kommunerne. Der er også samarbejder mellem kommuneforeningerne og de statslige myndigheder i de enkelte lande, hvor Finland er længst fremme gennem organiseret og formaliseret samarbejde.

Der er i alle nordiske lande en stor variation $\mathrm{i}$, hvor langt de enkelte kommuner er $\mathrm{i}$ arbejdet med at omstille til en mere cirkulær kommune. Der findes et utal af forskellige eksempler på cirkulære tiltag i de nordiske kommuner, fra små konkrete projekter til store tværkommunale projekter inden for alle aspekter af den cirkulære økonomi.

\subsection{Norge}

3.1.1 Hvad gør KS for at drive og støtte initiativer og politikker indenfor cirkulær økonomi?

KS har i 2018 gennemført en forskningsundersøgelse om affaldspolitik og cirkulær $ø$ konomi og brugt denne undersøgelse til at forsøge at skubbe på både nationalt og EU-niveau. Blandt andet har KS medvirket til at sikre, at der blev udarbejdet en national hvidbog for arbejdet med affaldshåndtering og cirkulær økonomi i Norge. KS har også sendt undersøgelsen til Europa-Kommissionens Circular Economy-interessentplatform. KS har videre etableret en referencegruppe med medlemmer fra de største byer i Norge.

KS har lavet en Youtube-video om den kommunale sektor og cirkulær økonomi, hvori det beskrives, hvordan kommunerne i fremtidens cirkulære økonomi vil være både samfundsplanlægger og bindeled i samarbejdet mellem det private erhvervsliv, 
forskningsinstitutioner og borgere ${ }^{4}$. KS ser den kommunale sektor som en vigtig drivkraft i omstillingen til cirkulær økonomi. Følgende punkter er særlig aktuelle og viser, hvordan norske kommuner kan bidrage til at få fart på den cirkulære økonomi:

\section{- Dialog og videndeling}

Affaldsbranchen, kommunesektoren og producenter bør tale mere sammen. Producenterne skal have mere viden om, hvordan de bør og ikke bør designe produkter, og kommunen har meget at bidrage med i den lokale samfundsplanlægning. For eksempel kan samarbejde mellem affaldsbranchen og kommunesektoren skabe bedre erhvervs- og boligområder og styrke det lokale arbejds- og uddannelsesmarked.

- Bruge erfaringerne til at inspirere Europa Norske kommuner er gået i front og har forsøgt forskellige løsninger. Nu kan de bruge erfaringerne til at vise, hvad der fungerer, og hvad der ikke gør. De kan inspirere andre lande og vise vej. I EU anvender mange af nationalstaterne endnu deponier, der modtager meget store mængder affald. Disse lande møder samme krav fra EU som Norge når det gælder nyttiggørelse. Her kan norske kommuners erfaringer hjælpe landene til en bedre affaldshåndtering.

- Bruge rollen som indkøber til at stille krav Kommunerne er store indkøbere. Det betyder, at de har påvirkningskraft. Sammen med affaldsselskaberne kan kommunerne stille krav til producenterne om, at produkterne skal være recirkulerbare. Livscyklusomkostninger og miljøkonsekvenser er krævende regnskaber, men affaldsbranchen har betydelig kompetence på feltet.

- Viden om hvad der fungerer og ikke fungerer Samarbejde med universiteter og læreanstalter kan styrke kompetencen indenfor affaldshåndtering og gøre omstillingen til cirkulær økonomi enklere. I dag er det i stor grad enkeltpersoner, som sidder på kompetencen, og den er i lille grad formaliseret. Der eksisterer få uddannelsesprogrammer og forskningsprojekter, som er relevante for at udvikle cirkulær økonomi og affaldshåndtering. Hvis dette kommer på plads, kan kompetencen, som affaldsbranchen sidder med i dag, blive spredt til flere dele af norsk arbejdsliv og økonomi.

- Mere samarbejde med affaldsbranchen

Affaldsområdet i Norge er i betydeligt omfang organiseret i fælleskommunale selskaber. Disse samles og samarbejder i stadig større grad, fordi der er behov for større organisationer og større indbyggergrundlag for at videreudvikle servicen. Store behandlingsanlæg kræver betydelige affaldsmængder for at være effektive. Derfor må indsamling og sortering af affald tænkes sammen. En fælles samordning gør det enklere at give indbyggerne en god og entydig information. Når kompetencer bliver samlet, driver det udviklingen fremad. Det betyder ikke 
nødvendigvis at affaldsselskaber bør slås sammen, men tæt samarbejde er en af nøglerne til succes. Da er det lettere at dele kompetencer og erfaringer, se et større billede og sikre effektiv drift af anlæg.

- God dialog med nationale myndigheder

Det er de nationale myndigheder, som bestemmer, hvilken retning Norge skal gå i, når det gælder affaldshåndtering og cirkulær økonomi. Dog er det vigtigt, at nationale, regionale og lokale myndigheder taler samme sprog og arbejder mod samme mål. God dialog og tæt samarbejde kan også her bidrage til bedst mulig udnyttelse af ressourcerne.

\subsubsection{Hvad er den generelle status på cirkulær økonomi i kommunerne?}

Kommunen har en afgørende rolle som ejer af de fælleskommunale affaldsselskaber, både ved at lægge præmisser for drift og som ordregiver for løsninger. Der er en række gode eksempler, hvor kommunerne udarbejder holistiske perspektiver i affaldshåndtering, for eksempel ved at samarbejde med andre kommuner for at investere i større sorterings- og behandlingsanlæg eller ved at koordinere andre kommunale planlægningsopgaver med affaldshåndtering. Et eksempel på sidstnævnte er Bergen kommune og deres "Bossnett", der er et automatiseret affaldssystem bygget under byens centrum. Det krævede et større udgravningsarbejde, som blev koordineret med andet infrastrukturarbejde på grund af klare meldinger fra kommunen.

Organiseringen med fælleskommunale selskaber har givet betydelige gevinster med hensyn til mere effektive tjenester og udvikling af nødvendig ekspertise. Samtidig ses det, at afstanden mellem affaldstjenester og resten af den kommunale organisation mange steder er blevet større. Det gør det vanskeligere for kommunerne at opnå tværsektorielle diskussioner og resultater - som igen er vigtige for at opfylde potentialet i den cirkulære økonomi.

Kommunerne bør se den cirkulære økonomi i sammenhæng med andre mål, som for eksempel arbejdskraftinddragelse af arbejdstagere uden meget formel kompetence. Oslo Kommune har for eksempel startet et pop-up-cykelværksted, der drives af unge flygtninge, der har brug for både arbejde og uddannelse. Således bliver unge flygtninge uddannet til at reparere cykler og får arbejdstræning og sprogundervisning, mens andre beboere får deres cykler repareret, hvilket forlænger cyklernes levetid. Sådanne foranstaltninger bidrager til den cirkulære økonomi, og giver kommunen mulighed for at tilbyde arbejdsuddannelse til dem, der har brug for det. Hertil kommer, at et øget fokus på dette område kan skabe rammer for samarbejde med lokale iværksættere og øge væksten i socialt iværksætteri.

\subsubsection{Strategier, politikker eller programmer på nationalt plan}

Regeringens "Strategi for grønn konkurransekraft" fra oktober 2017, skal bidrage til at give forudsigelige rammer for den grønne omstilling i Norge. Strategien præsenterer syv principper og en samlet politik, der skal styrke konkurrenceevnen i det private erhvervsliv og bidrage til at omstille Norge til et lavemissionssamfund. 
For at fremme den cirkulære økonomi vil regeringen:

- Arbejde for et styrket marked for sekundære råvarer i samarbejde med industri og affaldsbranchen.

- Videreudvikle og tydeliggøre regulering for at øge nyttig og miljøforsvarlig brug af affald og let forurenede materialer.

- Øge materialegenvinding, udrede krav om udsortering af organisk affald og plast og vurdere udvidet producentansvar for flere affaldstyper.

- Styrke efterspørgslen for cirkulære løsninger ved at videreføre dagens garantiordninger og samarbejde med EU for at styrke mærkeordninger, som fremmer grønne forbrugsmønstre.

Det norske parlament vedtog et lovforslag om ny affaldslovgivning og cirkulær økonomi i foråret 2018 baseret på regeringens hvidbog. I modsætning til Finland er der ingen national strategi for cirkulær økonomi. Der har været en øget interesse for forurening af plast og affald på havet. I foråret deltog 90.000 frivillige i en kampagne for at rengøre strande og natur fra affald. Den norske regering ønsker at spille en hovedrolle i forebyggelsen af affald i havet og plastaffald, men det er ikke forbundet med cirkulær økonomi.

\subsection{Danmark}

3.2.1 Hvad gør KL for at drive og støtte initiativer og politikker indenfor cirkulær økonomi?

Kommunerne har en helt central rolle i at understøtte den cirkulære omstilling lokalt, som bindeled, myndighed og i partnerskab med borgerne og virksomhederne. At arbejde med cirkulær økonomi i kommunen handler derfor om en kredsløbsfokuseret grøn omstilling i alle forvaltninger og i kommunens aktiviteter. Igennem planlægning, myndighedsopgaver, indkøb, udbud og erhvervsfremmeindsatser, handler det om at accelerere den cirkulære omstilling i erhvervslivet og services til borgerne.

KL's inspirationskatalog "Den Cirkulære Kommune" til landets kommuner beskriver hvad cirkulær økonomi er og kan være i en kommunal kontekst, herunder hvilke potentialer det rummer og hvilke indsatser, der kunne sættes i gang lokalt. Der fremgår også konkrete eksempler på og anbefalinger til, hvordan cirkulær økonomi kan tænkes ind $\mathrm{i}$ kommuners arbejde. Kataloget er inddelt $\mathrm{i}$ fire hovedtemaer:

- Strategi, plan og forsyning

- Erhvervsudvikling

- Indkøb og udbud

- Byggeri og anlæg 


\subsubsection{Hvad er den generelle status på cirkulær økonomi i kommunerne?}

Der findes en lang række gode eksempler på danske kommuner, der er gået i gang med at indarbejde cirkulær økonomi i egen forvaltning; i indkøbspolitikkerne, i udbudsmaterialer og i større bygge- eller anlægsprojekter og i den måde man forvalter sin forsyning (vand, spildevand, affald og energi). Det ses bl.a. i, at der findes deciderede cirkulær økonomi strategier eller elementer heraf i mange kommuner, både i de overordnede kommuneplaner eller for eksempel i erhvervs- eller forsyningsstrategien for området. Videre er der mange kommuner, der enten individuelt eller i fællesskab arbejder med cirkulær økonomi som en del af de erhvervsfremmetilbud, de tilbyder til lokale virksomheder.

\subsubsection{Strategier, politikker eller programmer på nationalt plan}

Den danske regering har i september 2018 offentliggjort en national strategi for cirkulær økonomi; "Strategi for cirkulær økonomi - Mere værdi og bedre miljø gennem design, forbrug og genanvendelse" ${ }^{\prime \prime}$. Af strategien fremgår det, at regeringen vil igangsætte initiativer indenfor seks temaer:

- Styrke virksomhederne som drivkraft for den cirkulære omstilling

- Understøtte cirkulær økonomi gennem data og digitalisering

- Fremme cirkulær økonomi gennem design

- Endre forbrugsmønstre gennem cirkulær økonomi

- Skabe et velfungerende marked for affald og genanvendte råvarer

- Få mere værdi ud af bygninger og biomasse.

Det er særligt relevant for de danske kommuner at byde ind på initiativer, der er koblet til affaldsområdet, hvor der er fokus på, at få en mere ensartet indsamling af husholdningsaffald og at der skabes mere lige vilkår på markedet for affald og genanvendte råvarer. Derudover kan kommunerne bidrage ved at fremme cirkulær forretningsudvikling i små og mellemstore virksomheder, at fremme cirkulære indkøb og øge fokus på totaløkonomi i offentlige indkøb og arbejde med at udbrede selektiv nedrivning.

Regeringen har indgået en partnerskabsaftale med KL og Danske Regioner om at etablere cirkulære kommuner og regioner med henblik på at udvikle og afprøve nye cirkulære løsninger i praksis. Partnerskabet skal medvirke til at inspirere andre kommuner og regioner og påpege eventuel justering eller forenkling af statslige regler.

5 Strategien kan ses her: https://mfvm.dk/fileadmin/user_upload/MFVM/Miljoe/Cirkulaer_oekonomi/Strategi_for_cirkulaer_oekonomi.pdf 


\section{$3.3 \quad$ Sverige}

\subsubsection{Hvad gør Sveriges Kommuner och Landsting (SKL) for at drive og støtte initiativer og politikker indenfor cirkulær økonomi?}

Klimaproblemet er den af SKL's politiske prioriteringer, som er koblet tættest til cirkulær økonomi. I denne sammenhæng arbejder SKL blandt andet for at fremme indkøb, der tager højde for bæredygtighed og reduceret klimapåvirkning og energiforbrug fra et livscyklusperspektiv.

SKL's arbejde på cirkulær økonomi varetages også indenfor den fælles ramme af FN's Verdensmål, og handler primært om at informere om, hvordan kommunerne kan anvende de globale mål som inspiration og støtte for egne strategier. SKL følger bl.a. arbejdet under den nationale Agenda 2030-delegation, og medvirker i FN-forbundets projekt "Glokala Sverige", for at støtte og stimulere gennemførelsen af de globale bæredygtighedsmål i Sverige.

Derudover er flere lovgivningsmæssige forslag og andre initiativer, for eksempel inden for plast, affald, plantesundhed, indkøb mv., en del SKL's nuværende indsats for cirkulær økonomi. Et konkret eksempel er SKL's arbejde med konferencer, ordregrupper og samarbejde med andre aktører for at reducere miljøbelastningen af kunstgræs.

\subsubsection{Strategier, politikker eller programmer på nationalt plan og $i$ kommunerne}

Cirkulær økonomi er blot et af flere navne til forskellige initiativer til bæredygtig udvikling i Sverige, både i stat og kommuner, landsting og regioner. Investeringer med et klart link til den cirkulære økonomi omfatter overskrifter som Fossilfrit Sverige, bæredygtig byudvikling, bæredygtig produktion- og forbrugsstrategi, Agenda 2030, mobilitet og bæredygtig transport, fordoblingsmål for offentlig transport, bioøkonomi, innovation, digitalisering mv.

En regeringsrapport om cirkulær økonomi blev præsenteret i 2017 med forslag til at fremme øget ressourceeffektivitet og genanvendelse. Blandt andet blev der foreslået skattelettelser for visse tjenester, øget mulighed for at reklamere for produkter, muligheden for bilparkering og støtte og krav til affaldsforebyggende foranstaltninger i staten og kommunerne.

Den sveske regering besluttede i foråret 2016 at iværksætte en undersøgelse med opgaven at undersøge og foreslå instrumenter til forebyggelse af affaldsmængder og for at fremme en cirkulær økonomi. Undersøgelsens hovedopgave var at analysere og foreslå instrumenter til fremme af øget udnyttelse og øget genanvendelse. Der skal findes incitamenter til både producenter og forbrugere til at fremme handel med brugte produkter samt stimulere reparationer og opgraderinger af produkter. Missionen vil primært fokusere på produkter beregnet til forbrugermarkedet.

På baggrund af undersøgelsen besluttede den svenske regering i 2018 at nedsætte en særlig delegation for cirkulær økonomi. Delegationen skal rådgive regeringen, udar- 
bejde en strategi for området samt identificere barrierer og behov for uddannelse og information om cirkulær økonomi. Videre skal delegationen være et videnscenter og en samordnende kapacitet for regeringen både på regionalt og nationalt niveau. En anden lignende platform er "Rådet för miljösmart konsumtion", som drives af Konsumentverket.

Et eksempel er RE:Source, der er et strategisk innovationsprogram for ressourcer og affald, som har støttet et stort antal projekter med cirkulær økonomi i centrum for aktiviteterne.

\subsection{Finland}

\subsubsection{Hvad gør Kuntaliitto for at drive og støtte initiativer og politikker indenfor cirkulær økonomi?}

Kuntaliitto, den finske kommuneforening, har en række aktiviteter i gang, der omhandler cirkulær økonomi. En af aktiviteterne er, at Kuntaliitto sammen med den finske innovationsfond, SITRA, har organiseret en konkurrence til at finde eksempler på best practice i de finske kommuner, for at sætte fokus på de kommuner der har fundet brugbare løsninger.

Kuntaliitto er i øvrigt en del styregruppen for Finnish Sustainable Communities' (FISU) Network for frontløbere, der har forpligtet sig til at blive $\mathrm{CO}_{2}$-neutrale, affaldsfrie og bekæmpe overforbrug inden 2050.

Kuntaliitto deltager videre aktivt $\mathrm{i}$ blandt andet styregruppen for projektet CIRCWASTE, der er et syvårigt LIFE-projekt under det finske miljøinstitut, som fokuserer på at skabe mere virkningsfuld anvendelse af materialeflows, affaldsforebyggelse og nye koncepter for affalds- og ressourcehåndtering. Endelig er Kuntaliitto på vej med egne træningsforløb og aktiviteter.

\subsubsection{Hvad er den generelle status på cirkulær økonomi i kommunerne}

Der er i Finland, som også i de øvrige nordiske lande, en vis variation i, hvor langt de enkelte kommuner er i arbejdet med omstilling til en mere cirkulær kommune. Nogle steder er cirkulær økonomi en integreret del af by- eller kommunestrategien, som følges op med konkret implementering. Andre kommuner er endnu i gang med pilotprojekter på forskellige områder.

Affaldshåndteringsområdet er formentlig det område, hvor udviklingen i de enkelte kommuner ligner hinanden mest, og hvor der er de største sammenfald i integrationen af projekterne. På trods af det, er der ikke en bestemt rolle, som de finske kommuner har valgt $i$ arbejdet med cirkulær økonomi. Flere arbejder med cirkulær økonomi i forbindelse med erhvervsfremme, for eksempel i særlige CØ-erhvervsparker, og andre er fokuserede på projekter i egen forvaltning. 


\subsubsection{Strategier, politikker eller programmer på nationalt plan}

Den finske regering satte allerede tilbage i 2015 et strategisk mål om at være frontløber på den cirkulære dagsorden. I 2016 kunne Finland derfor lancere verdens første nationale cirkulære økonomi roadmap, som er en solid plan med konkrete projekter og klar rolle- og ansvarsfordeling.

Mere end 50 forskellige organisationer fra både det private erhvervsliv, det offentlige og fra civilsamfundet har deltaget og bidraget til strategien. Køreplanen er forankret i SITRA og skal materialisere sig særligt indenfor seks områder; et bæredygtigt fødevaresystem, cirkulært skovbrug, tekniske kredsløb, transport og logistik og fælles aktiviteter mellem aktørerne. 


\section{En organisatorisk model til cirkulær økonomi}

Hvor omstillingen til mere cirkulære forretningsmodeller efterhånden er velbeskrevet for private virksomheder og organisationer, er den omstilling, der skal ske i den kommunale organisation, mindre belyst.

Denne guide belyser en hel række eksempler fra de nordiske lande, hvor tilgangen og arbejdsmetoderne har været forskellige, og det kan med det samme slås fast, at der ikke findes én rigtig metode til at arbejde med cirkulær økonomi. Der er eksempelvis stor forskel på, om en kommune deltager i et enkeltstående pilotprojekt på et af de områder, hvor der endnu ikke er opdyrket stor erfaring, eller om kommunen integrerer cirkulær økonomi som en del af sin samlede vision. Men sikkert er det, at skal den offentlige organisation høste afkastet af og skabe værdi ved cirkulær økonomi, så skal den på lige fod med den private sektor integrere cirkulær økonomi i sin forretningsmodel og i måden, hvormed den skaber og leverer værdi for borgere og virksomheder.

For at kunne gøre det, skal kommunen arbejde med cirkulær økonomi på tværs af forvaltningerne. Men viden og erfaring med cirkulær økonomi er ikke lige veludbygget på alle områder. Det betyder i praksis, at man på nogle områder kan implementere afprøvede cirkulære arbejdsgange og metoder i forvaltningen, mens der er andre områder, hvor man må arbejde med udviklingsprojekter for at opbygge den fornødne kompetence.

At arbejde cirkulært er derfor ikke alene et spørgsmål om faglighed på ressource- og materialestrømme. Det handler i lige så høj grad om, at få gearet sin organisation til at kunne håndtere de cirkulære modeller og metoder. Og da cirkulær økonomi fokuserer på at optimere ressourcestrømme og kredsløb internt og eksternt i organisationen, vil arbejdet per definition fordre, at der arbejdes på tværs af ressortområder og fagligheder.

Guiden til omstilling til en cirkulær kommune er derfor struktureret ud fra en organisatorisk model ${ }^{6}$ med anvendelse af syv organisatoriske elementer anvendt som rettesnor for en ensartet og struktureret analyse af de nordiske tiltag inden for cirkulær $ø$ øonomi. Modellen udgør en ramme for forståelsen af den kommunale organisatoriske opbygning, der muliggør udvikling og implementering af nye cirkulære projekter, ligesom den udgør en rettesnor for den fremtidige tilrettelæggelse af en samlet cirkulær indsats.

${ }^{6}$ Modellen er udviklet af PlanMiljø og anvendt ved en lang række nordiske og internationale projekter. 
- $\quad$ Er der en overordnet vision for cirkulær økonomi i kommunen, og udviser kommunens politiske og administrative top tydeligt lederskab i forhold til cirkulær økonomi?

- Er der fastlagt en overordnet strategi for cirkulær økonomi i kommunen, har der været en klar plan for projektet?

- Har medarbejderne de rigtige og tilstrækkelige kvalifikationer til projektet, er medarbejdere og interessenter engagerede og tager ejerskab?

- Understøtter kommunens kultur den brede cirkulær økonomi-indsats og de konkrete projekter, og er der etableret en struktur - dvs. fordeling og koordineringen af arbejdsopgaver og ansvar som styrker arbejdet med cirkulær økonomi?

- Har kommunen fundet frem til de rigtige systemer til at understøtte cirkulær økonomi projekter?

- Er der midler og kanaler til effektiv kommunikation?

- Er der indgået de rigtige partnerskaber til at gennemføre indsatserne?

De organisatoriske elementer hænger tæt sammen og giver samtidig rum og værktøj til at se hvert projekt fra forskellige sider og belyse fordele og ulemper ved det organisatoriske set-up. Indsatser inden for hvert af de organisatoriske elementer kan understøtte den gradvise omstilling til cirkulær økonomi i kommunen - men alle elementer skal i spil, hvis cirkulær økonomi for alvor skal forankres i kommunen.

De nordiske kommuner har varierende indsatser på området, og der findes forskellige måder at opnå miljømæssige, økonomiske og sociale fordele gennem omstilling til en cirkulær økonomi. I en kommunal sammenhæng er det at have formuleret en stærk og klar vision og ledelsesmæssig opbakning helt centrale elementer for muligheden for at omstille sig til den cirkulære økonomi. Kommuner har - og også i højere grad end andre organisationer - et stærkt ønske og behov for at involvere en bred kreds i formuleringen og ejerskabet af visionen - både borgere, virksomheder og andre partnere. Kommunernes ledelse består af det folkevalgte byråd/ kommunalbestyrelse og den administrative ledelse, og disse to ledelsesniveauer skal være i trit, for at større og gennemgribende indsatser kan lykkes. Også inddragelsen af andre aktørgrupper har stor værdi for at gøre den cirkulære økonomi til virkelighed $\mathrm{i}$ kommunen.

- Borgerne kan overordnet engagere sig med konkret input til kommunens politikker og regulering. Mere praktisk kan borgerne som forbrugere bidrage til, at ressourcerne holder sig længere i en aktiv livsfase ved at købe kvalitetsprodukter, reparere og videregive til genbrug, når produktet ikke længere har brugsværdi for den enkelte.

- Erhvervslivet kan indgå partnerskaber med kommunen om at udnytte cirkulære muligheder i specifikke værdikæder - det være sig fødevarekæder i kommuner med en stor landbrugssektor eller for eksempel plast-varekæder i mere industriprægede kommuner. Mere generelt kan erhvervslivet stræbe mod at frembringe produkter, som med lang levetid og mulighed for reparation og ressourcegenanvendelse i sig selv bidrage til den cirkulære økonomi. 


\subsection{Vision og lederskab}

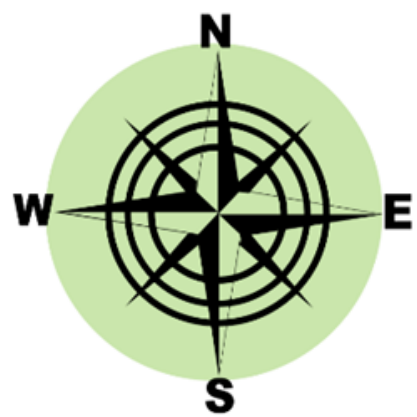

Politikere og ledere skal have sat cirkulær økonomi på dagsordenen i kommunen, og det indebærer ændringer i både paradigmer og praktiske indsatser. Fokus skal skifte fra den lineære økonomi med dens spild af ressourcer til en ny tilgang, hvor værdikæder ideelt set starter og slutter det samme sted.

Den cirkulære tankegang er relevant at introducere for alle de dele af kommunens forvaltning, hvor der er forbrug af ressourcer og/eller erhvervsudviklingsmuligheder. Hvor der er størst potentiale, kan afklares med en analyse af kommunens ressourcekredsløb og væsentlige erhvervssektorer, og ofte vil indsatsen fokusere på de fire allerede skitserede temaer:

- Kommunens indkøbspolitik og -afdeling er ofte et godt sted at starte. Det kræver ekstra ressourcer og en vis risikovillighed at indkøbe cirkulært. Her kan ledelsen vise vejen ved at opmuntre til nytænkning, acceptere udfordringen og sigte på indkøb af kvalitetsprodukter med lang levetid, mulighed for reparation og genbrugs- og genanvendelsespotentiale. Indkøbsfunktionens succes skal måles på evnen til at holde ressourcerne i spil og ikke kun i forhold til de rå indkøbspriser. Det kan være vanskeligt at arbejde med cirkulære indkøb, både fordi det i praksis kræver nytænkning af medarbejderne, og fordi der kan være andre legitime hensyn i indkøbspolitikken, for eksempel økonomi. Derfor er der brug for en samlet vision på området.

- En visionær affaldspolitik med fokus på forebyggelse, genbrug og genanvendelse sender en tydelig besked til medarbejderne på affaldsområdet: Vi skal have fokus på at undgå affald ved intelligent indkøb og forbrug; vi skal påvirke forbrugsmønstre, så genbrug styrkes; vi skal tilrettelægge affaldsordningerne, så de peger mod de bedste genanvendelsesscenarier; og så skal vi følge de fraktionsindsamlede ressourcer til dørs og sikre, at de rent faktisk genanvendes.

- På området for byggeri og anlæg formidler en samlet vision om cirkulær økonomi vigtige retningslinjer til hele værdikæden - fra råvareleverandører til arkitekter, entreprenører og nedrivningsfirmaer - om at der efterspørges bygninger, som kan bruges til forskellige formål, og hvor materialerne kan genanvendes efter nedrivning. 
- Erhvervslivet vil udfylde en vigtig rolle i byernes cirkulære fremtid. Kommunens vision og et aktivt lederskab kan være udgangspunktet for partnerskaber, hvor kommune og erhvervsliv sammen udforsker og udnytter mulighederne for fremtidsorienterede, cirkulære løsninger.

I Aalborg Kommune (DK) er der stor opbakning til arbejdet med cirkulær økonomi fra såvel politikere som direktører, også da kommunen stod foran et stort, nytænkende udbud:

Man skal beslutte sig for dette helt op på ledelsesniveau, der skal være tydelig ledelsesopbakning. Hvis der er nogen, der begynder at bakke ud af projektet, fordi det er svært og ikke er "som vi plejer", så kan man henvise til den politiske vision.

Birgitte Krebs Schleemann, Projektleder, Aalborg Kommune

Både den politiske- og administrative ledelse havde udstukket kursen og turde stå ved prioriteringen - selv med de risici, der fulgte med. Den øverste ledelse giver medarbejderne troen på, at det kan og tør vi godt, også selvom man går utraditionelle veje.

Case 7

Det er ledelsens ansvar, at ambitionerne om cirkulær økonomi bringes videre til medarbejdere, borgere og virksomheder. Der skal etableres kommunikationslinjer, så kommunen kan motivere og aktivere aktørerne og samtidig modtage inspiration, som kan bidrage til både enkeltprojekter og nye visioner. Det kan ske på mange forskellige måder og med forskellige virkemidler - for eksempel seminarer, temadrøftelser i byrådet, konferencer med det lokale erhvervsliv eller egentlige netværk med borgere og virksomheder til støtte for den cirkulære indsats. Denne ledelsesindsats hænger godt sammen med udarbejdelsen af en cirkulær vision, der skal bruges som løftestang for strategien og de kommende projekter.

En klar vision for den cirkulære økonomiske udvikling sikrer fælles retning og fodslag for hele organisationen og samarbejdspartnerne. Visionen viser, hvor kommunen vil hen på lang sigt, og giver aktørerne en fælles forståelse af de overordnede mål og principper for indsatsen. Den gode vision er attraktiv, realistisk og troværdig, så den kan inspirere medarbejdere og interessenter i det daglige arbejde, vanset hvilken forvaltningsgren i kommunen man er en del af.

I Jyväskylä Kommune (FI) er cirkulær økonomi en strategisk del af kommunens vision.

Lederskabet er helt afgørende for succes med den cirkulære indsats. Uden lederskabet vil alle de enkelte initiativer ikke føre til vedblivende forandring.

Pirkko Melville, R\&D Manager, Jyväskylä (FI)

Case 4 
Cirkulær økonomi er et strategisk helhedssyn, der kan være med til at udnytte potentialerne i kommunens overordnede vision, herunder sikre bedre anvendelse af både menneskelige og fysiske ressourcer. Kommunen har det lange lys på, og den cirkulære økonomiske tankegang er med til at skabe innovation, fordi det grundlæggende handler om, hvordan tingene kan gøres ressourceeffektivt, nemmere, smartere og billigere. Visionen kan omfatte både samfundets, erhvervslivets, medarbejderes og borgeres behov. Når visionen bliver udarbejdet, er det essentielt at give alle mulighed for at bidrage. Dermed skabes en vision, som aktørerne kan se sig selv i, og som virker bredt motiverende for alle.

I Borgå (FI) er byens overordnede mål at blive frontrunner for cirkulær økonomi og skabe gode forhold og gøre det lettere for arbejdet med dette hos både borgere og virksomheder. Kommunen har udarbejdet en 2030-vision for byen, der bl.a. betoner, at Borgå er en by, der fremmer cirkulær økonomi, skaber nye forretningsmuligheder for virksomhederne og støtter borgerne $i$ at tage bæredygtige valg.

Se strategien her

Egentlig integration af cirkulær økonomi i kommunen vil betyde, at indsatsen går på tværs af forvaltningsområder, og store dele af opgaveløsningen vil afhænge af interne såvel som eksterne partnere. Når en mindre andel af den samlede opgave ligger inden for én direktørs eller én projektlederes ansvarsområde, er det i særdeleshed afgørende for succes, at der ligger en politisk vision eller mandat bag strategien.

\subsubsection{Hvordan sikres en god vision?}

Visionen for cirkulær økonomi skal ses i relation til kommunens stedbundne potentialer, kvaliteter og ressourcer. Man bør tage afsæt i den lokale identitet og gøre brug af kommunens særlige karakteristika - for eksempel storby, provinsby, land, øer, små- og mellemstore virksomheder, børnefamilier, landbrug, sport, events, havnen, fiskeriet, naturen. Ved at koble den cirkulære strategi op på identitetsbærende temaer kan kommunen sikre samhørighed med borgerne, det lokale erhvervsliv, partnere og investorer.

Aarhus Kommune (DK) har med Aarhusmålene og klimastrategien lagt en ambitiøs og bæredygtig linje for Aarhus Kommunes cirkulære arbejde.

Cirkulær økonomi er en stor del af kommunens indkøbspolitik, og der arbejdes med cirkulær økonomi i alle udbud, hvor det giver mening. Visionen er ført videre i en kommunal strategi over, hvordan cirkulær økonomi bedst muligt kan inkorporeres i udbud.

Case 5,32 og 33

7 https://www.borga.fi/library/files/5bacc533ed6b97b70400082d/kaupunkistrategia_ruotsi.pdf 
I arbejdet med visionen kan kommunen med fordel inddrage samarbejdspartnere, forsyningsenheder (affald, vand, spildevand, energi) samt byggeri og anlæg, og dermed skabe overblik over mulighederne inden for kommunens store produktions- og forbrugskredsløb. Dertil kommer de enkelte forvaltningsgrene som for eksempel sundhed, børn og unge og socialområdet. Klare og konkrete målsætninger sikrer, at hele kommunen og de enkelte forvaltninger ved, hvad de skal arbejde mod, og hvad der måles på for at følge indsatsen til dørs. Det gør det nemmere for indkøbere, bygherrer og byplanlæggere, når indsatserne skal udformes i hverdagen.

Gode råd til visionen:

- Formuler i visionen hvad indsatsen for cirkulær økonomi skal føre til - hvad vil kommunen opnå?

- Når medarbejdere og ledelse udarbejder visionen sammen, giver det ejerskab og motivation.

- Luk også borgere og erhvervsliv ind i visionsprocessen. Det har stor værdi for samarbejdet og for forståelsen af de overordnede hensigter.

- Formuler visionen let forståelig og dragende, så større udbredelse og kendskab muliggøres.

Den cirkulære økonomi er relevant på stort set alle områder, hvor kommunerne i forvejen har lokale planer og politikker såsom kommunal- og lokalplan, klima, affald, fødevarer, indkøb og erhverv. Her kan der tilføjes cirkulære aftryk og tænkes cirkulært, når planerne skal opdateres - afhængig af, hvor kommunen prioriterer sin indsats.

Erfaringen viser, at spændende cirkulære indsatser meget vel kan udvikles uden de store overordnede politiske visioner på området, og mange kommuner arbejder allerede med elementer af cirkulær økonomi uden nødvendigvis at have hægtet disse op på en overordnet vision. Ofte er det netop enkeltstående, succesfulde cirkulære projekter, som skaber opmærksomhed på nye løsninger og bringer cirkulær økonomi ind på den kommunalpolitiske dagsorden. Det giver cirkulær økonomi mere opmærksomhed og kan direkte implementeres i de overordnede visioner, politikker og planer for kommunen.

Men styrken ved en samlet vision er, at den tjener til at skabe en kommunal sammenhængskraft i den cirkulære indsats, hvilket over tid vil påvirke aktører og fælles kultur i retning af bedre ressourceudnyttelse og større bæredygtighed.

Endelig vil en samlet vision for den enkelte kommune have større gennemslagskraft og være mere troværdig, hvis den kan have ophæng i en national vision for hele samfundets omstilling til en cirkulær økonomi. En samlet national vision og strategi giver kommuner såvel som det private erhvervsliv mulighed for at samtænke deres initiativer, og kommunerne imellem vil det sikre fælles fodslag til at levere på den kommunale del af den samlede offentlige opgavevaretagelse. 
CASE: Vision for cirkulær økonomi som brandingværktøj for landdistrikter

Samsø Kommune vil være det første sted i verden, hvor cirkulær økonomi er fuldt implementereret.

Begrebet cirkulær økonomi hviler på hele bæredygtighedstankegangen, og på Samsø udgør cirkulær økonomi en ramme for innovation og vækst ved at gå på tværs af bæredygtighed, teknik, forretning og biologisk materiale. Sams $\varnothing$ vil være udstillingsvindue for cirkulær økonomi og bioøkonomi, så hele verden kan se, at en 100 procent omstilling til cirkulær $\varnothing$ konomi kan lade sig gøre.

Sloganet i kommunen er: "Det bliver på Samsø", og visionen er at holde ressourcerne - både de menneskelige og de materielle - på øen. For Samsø handler det ikke alene om at gøre noget godt for miljøet. Det handler også i høj grad om vækst, og cirkulær økonomi er et aktivt værktøj til at promovere øen og tiltrække både økonomiske interesserer og nye borgere:

Der har været et problem med befolkningsfald på øen, men prognosen siger nu, at befolkningstallet kommer til at stige. Den brandingeffekt, vi har haft med den vedvarende energi og den cirkulære økonomi, er helt sikkert med til at gøre det til et attraktivt sted at flytte hen for personer, der gerne vil beskæftiges inden for denne sektor.

Samsøs vision om en cirkulær økonomisk ø giver unikke brandingmuligheder. Lige så vigtigt er det, at visionen har hjulpet til at tage hul på diskussionen om, hvor det lille lokalsamfund vil hen, - både internt i kommunen og ude blandt borgerne, og så har det helt konkret hjulpet til at bibeholde og endda skabe nye arbejdspladser til beboerne.

Den cirkulære vision bidrager til, at vi får snakket konkret om cirkulær økonomi i kommunen. Det handler om at få løftet den politiske ambition og om et levedygtigt lokalsamfund. Hvis vi kan udnytte ressourcer til at skabe lokale jobs, så er det jo herligt, og så er der også et ønske om, at vi skal bruge de lokale kræfter. Søren Stensgaard, Teknisk forvaltningschef, Samsø (DK)

For Samsø har det cirkulære arbejde været en kilde til nytænkning, og visionen om et cirkulært samfund har båret frugt og sat Samsø på verdenskortet. Arbejdet er langt fra færdigt, og kommunen har en masse nye projekter i støbeskeen, men rådet lyder alligevel:

Lad være med at gøre det for kompliceret - bare kom i gang. Lav en vision, få den forankret både politisk og $i$ kommunes ledelse og så bare kom i gang og få de første erfaringer, som kan underbygge visionen!

Pointerer Søren Stensgaard, Teknisk Forvaltningschef i Samsø Kommune. 


\subsection{Strategi}

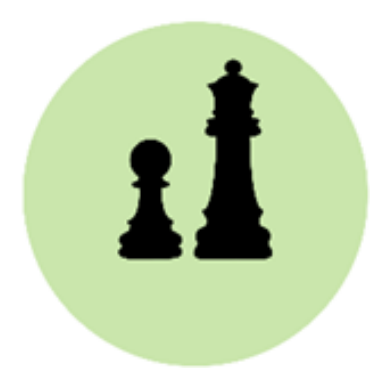

Vejen fra at have en idé eller vision om cirkulær økonomi til cirkulær økonomi bliver en del af den politiske og administrative styring, kan være lang og snørklet. Den enkelte kommune må finde sin egen retning, afhængig af den politiske og administrative kontekst og af ambitionen for cirkulær økonomi. En strategi omsætter de politiske mål og rammer til konkrete indsatser i kommunens forvaltninger. Mens nogle kommuner vælger at udforme en samlet strategi for cirkulær økonomi, arbejder andre med at integrere cirkulær økonomi i eksisterende strategier og politikker i kommunen. Og begge dele kan fungere fint.

Det væsentlige ved en cirkulær kommunestrategi er, at den konkretiserer initiativer, der sætter skub i omstillingen til en mere bæredygtig kommunal praksis, hvor man recirkulerer materialer og produkter, udnytter deres værdi til fulde og minimerer spildet. Omstillingen rummer potentielt store gevinster for både miljø og økonomi i hele kommunen. En strategisk indsats på cirkulær økonomi kan ses som en satsning, der samler mange forskellige bæredygtige initiativer (for eksempel inden for de fire temaer i denne guide) under én paraply. En cirkulær kommunestrategi vil bygge oven på kommunens allerede eksisterende arbejde med bæredygtig og miljørigtig udvikling i kommunen. Samtidig kan kommunen - de enkelte forsyninger og forvaltningsgrene - udvikle nye indsatser sammen med borgere, virksomheder og uddannelsesinstitutioner.

\section{Strategiens indhold:}

- Langsigtet mål - Vision for projektet.

- Projektmål - Hvordan er situationen, når projektet er gennemført.

- Resultater-Hvad der skal produceres undervejs.

- Aktiviteter - En række handlinger som fører til de enkelte resultater.

- Ressourceindsats - Arbejdstimer og øvrige ressourcer, som skal til for at gennemføre aktiviteterne.

En cirkulær økonomistrategi skal fastlægge kommunens mere konkrete mål og vejene til at opfylde disse - altså: Hvor er vi, hvor vil vi hen, og hvordan kommer vi derhen?

Ved at koble den cirkulære strategi op på identitetsbærende emner - for eksempel produktion af fødevarer, turisme eller en stærk industri - kan kommunen sikre samhørighed med borgerne, det lokale erhvervsliv og investorer. Derudover kan kommunen 
få et styrket brand, som kan benyttes til at skabe synergier med erhvervsfremmeindsatser, arbejdsmarkedspolitik, socialøkonomi og uddannelse, - som det bl.a. er sket i Samsø Kommune (se case side 19).

\section{Pilotprojekter for cirkulær økonomi}

Indledende pilotprojekter kan være med til at bane vej for, hvordan en strategi for cirkulær økonomi kan udformes.

I Göteborg Kommune (SE) havde man en vision om ikke kun at reducere affald, men også at undersøge mulighederne for helt at undgå affald på udvalgte områder. I strategien er der udarbejdet modeller til en række arbejdspladser for, hvordan de kan undgå at skabe affald i deres daglige arbejde ved ganske enkelt at skabe nye rutiner.

Strategien bygger på to indledende pilotprojekter, hvor der blev tildelt nok tid og ressourcer til, at et grundigt stykke arbejde kunne udføres og skabe basis for den endelige model. Projektet var en stor succes og spredes nu både til virksomhederne i Göteborg by og til andre kommuner.

Case $8 \& 34$

Med strategien og tilhørende indikatorer kan det løbende måles, om kommunen, forsyningsselskabet og de enkelte forvaltninger lykkes med at opfylde målsætningerne. Formulering af mål og succeskriterier giver mulighed for en harmoniseret, målstyret indsats, som ledelse, medarbejdere, politikere og interessenter alle kan føle ejerskab over. Det kan i øvrigt være et væsentligt understøttende element, hvis strategien adresserer økonomien for enkeltindsatser og projekter, såvel som på tværs af enheder.

Den klare strategi sikrer sammenhæng i den cirkulære indsats, der arbejdes struktureret frem mod klare mål og resultaterne fremkommer i henhold til en plan. Men en manglende strategi for cirkulær økonomi er heldigvis ikke en uoverkommelig begrænsning for ihærdige medarbejdere i kommunen. Her skaber ildsjæle projekter ud fra gode ideer og tydelige behov, som kan ende ud i succes. Gennem disse projekter øges opmærksomheden på området og på mulighederne ved at arbejde konkret med cirkulær økonomi.

\subsubsection{Gode råd til strategien:}

- Lav en baseline for arbejdet, der giver et billede af den nuværende situation: Hvor er de væsentlige materialestrømme, hvilke aktive parter skal involveres, hvad er kommunens særlige styrker?

- Udform strategisk udvalgte mål, der er nemme at arbejde med i hverdagen for de enkelte forvaltningsgrene (en balance mellem det detaljerede og det overordnede).

- Formuler mål, som ligger i centrum af den kommunale kerneopgave - for eksempel inden for affaldshåndtering, folkeskole og ældrepleje.

- Målsætningerne kan være på flere niveaver og kan dække flere afdelinger i kommunen og udfordringer, der skal løses i partnerskab. 
- Skab sammenhæng mellem strategiens handlingsplaner og de tilgængelige ressourcer, så arbejdsbyrden er realistisk.

- Definer tydelige succeskriterier for indsatsen.

- Inddrag ledere og medarbejdere fra forskellige forvaltninger i udviklingen af strategien, så der skabes fælles målsætninger og handlingsplaner inden politisk behandling.

- Kommuniker om strategien for at sikre inddragelse og kendskab.

\section{Interessentinddragelse}

Da Jyväskylä Kommune (FI) skulle udvikle cirkulær strategi for kommunen, arbejdede de fra starten af tæt sammen med udvalgte repræsentanter fra stakeholder gruppen. Dermed var alle væsentlige aktørgrupper involveret i den langsigtede indsats for cirkulær økonomi. 30 aktører blev på baggrund heraf involveret i en følgegruppe for den cirkulære indsats, som repræsenterede både byen, uddannelsesinstitutioner, virksomheder, NGO'er og regionsråd.

Case 4

\section{Hent inspiration til strategiarbejdet}

Da Ronneby kommune i Sydsverige skulle i gang med at udforme en cirkulær strategi for kommunen, var et naturligt første skridt at undersøge og drage nytte af andres gode erfaringer på området. Derfor tog en delegation blandt andet til Holland, hvor de mødtes med både virksomheder og kommunale aktører og høstede gode erfaringer og ikke mindst god energi til det forstående arbejde:

In the Netherlands we met companies who were heavily involved in circular economy. We met public organisations and many other stakeholders. We were looking in to what is the strategy when it comes to sustainability in a broader sense and we really liked what we saw and presented it for the board in Ronneby.

Johan Sandberg, Enhetschef, Cefur

Tilbage i Ronneby blev de mange gode eksempler og møder en stærk inspirationskilde, der kom til at lægge grunden for den cirkulære vision og strategi i kommunen.

Case 20

\section{Kuopio er cirkulær økonomi blevet fremtiden}

I den finske kommune Kuopio vedtog byrådet i efteråret 2017 en ny kommunal strategi. Dette er ikke noget særsyn, men i Kupio har en bæredygtig dagsorden fået lov at gennemsyre strategien, og det er et nyt skridt for kommunen, der i starten af 2017 blev sammenlagt med nabokommunen Juankoski og dermed blev den niende største i Finland. I dag lyder missionen Kuopio with its partners create environments for sustainable growth and good life, og den cirkulære økonomi er indarbejdet som et helt centralt mål for kommunen frem mod 2030. 
During the project, management and representatives became more and more enthusiastic and it also helped that the city got awarded with a price for the work on circular economy. Now people know a lot more about circular economy and not least are proud of what we've achieved and want to work further with it.

Minna Kuuluvainen, projektkoordinator, Kuopio (FI)

Den nye strategi blev til gennem et intensivt samarbejde mellem kommunens mange interessenter - herunder politikere, universiteter, virksomheder, organisationer og borgere. Man indbød de forskellige aktører til dialogmøder. Desuden udformede man seks arbejdsgrupper med seks forskellige undertemaer, der alle havde de forskellige interessenter repræsenterede, og som fik mulighed for at diskutere mål og visioner for kommunen og udvikle på både strategi og roadmap.

Vejen mod fælles fodslag

Den fælles dialog og inddragelsen af de mange forskellige aktører har været helt centralt for arbejdet med strategien i Kuopio. Minna Kuuluvainen, projektkoordinator i Kuopio kommune, beskriver samarbejdet: It has been good to have so many stakeholders sitting together discussing the issue and not least the possibilities - this has been the key to success.

Omvendt var partnerskabet også en svær øvelse, der krævede noget tilvænning og til tider var vanskelig at styre i detaljer grundet de mange forskellige konstellationer, ønsker og behov. Kommunens borgere var for eksempel allerede fra start meget fokuserede på at få bæredygtighed med som et kernepunkt i strategien, hvorimod erhvervslivet var mere tøvende. Den store opgave lå derfor $\mathrm{i}$ at få de forskellige interessenter til at mødes. Dette skete gennem intensiv dialog, og i løbet af processen blev der skabt en fælles forståelse, der udmundede i, at cirkulær økonomi blev et af de fire kerneområder i strategien.

We've really learned to understand that we can not do this job or set the goals alone so we need the city to come with us to do this.

Minna Kuuluvainen, projektkoordinator, Kuopio (FI)

I Kuopio er man i dag stolte af den nye strategi og ikke mindst af processen med at få den udviklet. Desuden har kommunen høstet værdifulde erfaringer for det fremtidige arbejde, for i Kuopio er man godt klar over, at arbejdet langt fra er slut: Strategy is one thing - now the real work starts! 


\section{Erfaringer fra Kuopio til strategiarbejdet}

- Overvej om I kan drage nytte af en projektleder eller en styregruppe, der holder øje med slagets gang og har overblik over det større billede, og som samtidig er tovholder på dialogen med interessenter.

- Husk at cirkulær økonomi-arbejdet ikke slutter med en strategi. Sørg for at bevare kommunikationen med interessenter - også efter, at strategien er færdigudviklet.

- Vær bevidste om vigtigheden af at have det praktiske på plads - både planlægning, udførelse og opfølgning!

- Tag ud og mød folk, og udnyt muligheden for at fortælle om, hvad I arbejder med i kommunen.

- Grib muligheden for at lære af hinanden: Del erfaringer med for eksempel nabokommunen eller andre, der har gjort sig gode erfaringer - se dem ikke som konkurrenter, men som allierede. ${ }^{8}$

\subsection{Medarbejdere}

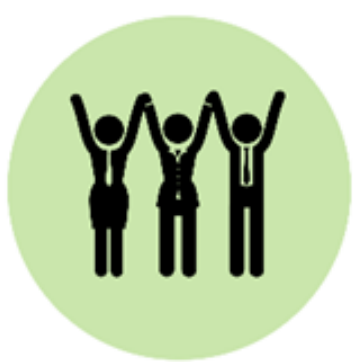

Med nye cirkulær økonomi-orienterede visioner og strategier står den kommunale forvaltning overfor ekstra udfordringer i forhold til at levere den ønskede kvalitet i opgaveløsningen, og det er helt nødvendigt at sikre forankring i medarbejdergrupperne. Kommunens medarbejdere (både fra forvaltningen og fra kommunens institutioner) er naturligvis centrale for at opnå de ønskede resultater - er de motiverede, findes de ønskede kompetencer, belønnes medarbejdere for tværgående samarbejde og er der reelt mulighed for at indarbejde cirkulær økonomi i daglig praksis?

Forankring sker ikke af sig selv, men er et resultat af en bevidst proces med inddragelse og motivering, hvor medarbejderne er med til at drøfte vision og strategi-og især de konkrete indsatser. Der er inden for kommunernes mange forvaltningsområder en stor faglig kompetence, der bør udnyttes til at tilrettelægge arbejdet med cirkulær økonomi. Hvor ledelsens rolle er at tage ansvar for og prioritere opgaven og have de organisatoriske briller på, så er det medarbejderne, der besidder den konkrete faglighed,

8 Ressourcevisdom og cirkulær økonomi i Kuopio, Finland: https://www.kuopio.fi/fa/resurssiviisaus-ja-kiertotalous 
som sikrer gode resultater. Det kræver dog, at (projekt)lederen hjælper de enkelte faggrupper med at se deres respektive fagligheder i lys af den cirkulære økonomi og evt. tilpasse medarbejdernes roller hertil.

\subsubsection{Medarbejdere og målgruppe}

Allerede i projektudviklingen bør det vurderes, hvilke kommunale institutioner og aktører, der skal involveres, idet der skelnes mellem egentlige partnere i projektet og målgrupper for projektets tiltag. Begge parter er altafgørende at engagere og en interessentanalyse, hvor de enkelte aktørers interesser analyseres, kan have stor betydning for et projekts udfald. I interessentanalysen skal de forskellige interessenter for projektet identificeres og grupperes efter krav og forventninger og betydning for projekt. Således kan projektet lægges til rette, så de relevante medarbejdere bedst bringes i spil.

Både Frederiksberg (DK) og Aalborg (DK) Kommune har haft stor succes med et inddrage interessenter og målgruppe i miljøarbejdet. Frederiksberg har længe haft en såkaldt Miljøambassadørordning, hvor hver institution har en fast ansvarlig repræsentant, der bliver kontaktpunkt for kommunens miljøpolitik i forhold til affald, energi, kemi, mad osv. Det sikrer lokal forankring og uddelegerer ansvaret for at igangsætte og vedholde nye indsatser om for eksempel medarbejdernes sortering både indeog udendørs.

Ud over at kommunikere via mails og nyhedsbreve afholdes der også kursusdag for ambassadører, så de får redskaber og kan sparre med andre ambassadører. Ved at have denne kontakt til målgruppen skabes der større chance for forandring og succes. Aalborg Kommune har etableret Grønne Agenter som et tilbud til borgere og institutioner, der kan rådgive og assistere i forbindelse med borgernære miljøprojekter og inspirere til en grøn dagligdag.

Case $10 \& 7$

Målgruppen skal især engageres, når intentionen er, at initiativet skal fortsætte efter afslutning af et pilotprojekt. I Göteborg (SE) havde man et mål om at forebygge mængden af affald. Her indgik man et samarbejde med plejehjemmet Sekelbo, hvor der allerede var interesse for emnet. Gennem øget fokus på de daglige arbejdsrutiner og på, hvordan disse kunne forbedres med fokus på affaldsreduktion, blev projektet hurtigt drevet videre af plejehjemmets aktive medarbejdere. Forvaltningens projektteam arrangerede en workshop med medarbejderne på plejehjemmet, hvilket gav værdifulde oplysninger og indsigt i deres rutiner og arbejdsopgaver og, hvor medarbejderne valgte hvilke affaldsfraktioner og hvilke opgaver, man skulle fokusere på i den efterfølgende reduktion af affaldsgenereringen.

I Asker Kommune (NO) havde man et ønske om indsamling og udsortering af tekstiler på genbrugsstationerne for dermed at minimere restaffaldet. Medarbejderne på genbrugsstationerne udførte en vigtig rolle i at sikre denne sortering i praksis hos brugerne, men det viste sig vanskeligt at få kommunikeret de nye regler for sortering af tekstiler videre til brugerne. Gennem møder og vejledninger fik de ansatte redskaber til at forbedre sorteringen og indsamlingen af tekstiler på stationerne. 


\subsubsection{Interne eller eksterne og hvor mange}

Alt efter projektets størrelse og kompleksitet kan det være relevant at inddrage eksterne medlemmer til projektteamet. I Aalborg Kommune (DK) viste det sig at være en god investering at inddrage en ekstern udbudskonsulent, som bl.a. kunne bistå med det juridiske arbejde for at kunne integrere cirkulær økonomi i proceduren for udbud. I Göteborg Kommune (SE) valgte man i pilotprojektet på Sekelbo at have en ekstern konsulent tilknyttet til at organisere og navigere det indledende arbejde.

I Asker Kommune (NO) ser de tilbage på et vellykket projekt med at optimere indsamling og genanvendelse af tekstiler, men er samtidig opmærksom på, at en ekstra antropolog på holdet kunne have givet endnu større indsigt i forbrugeradfærd og til at indgå i dialog med tekstilproducenter.

På samme måde ser Qeqqata Kommune (GL) tilbage på deres pilotprojekt med indsamling af bioaffald fra husholdingen, hvor en projektleder, der udelukkende havde været ansvarlig for dette projekt, kunne have sikret større succes.

\section{Skab stolthed hos medarbejderne}

Det skaber motivation, når den enkelte medarbejder kan tilrettelægge sine egne opgaver og være med fra start til slut. Samtidig har det også betydning for indsatsen, at medarbejderen selv kan se opgavens formål og kan påvirke resultatet, så det er arbejdet, der passer til medarbejderen og ikke omvendt.

I Jyväskylä (FI) går man meget op i, at medarbejderne altid høres, og at deres ideer testes. Medarbejderne har altid mulighed for at komme med nye ideer, som kan forbedre det samlede arbejde.

Begejstringen over at have været en del af et anderledes og succesfuldt projekt kan skabe medarbejder-ambassadører, der fremover kan bidrage til at styrke implementeringen af cirkulær økonomi.

Case 4

\subsubsection{Medarbejderne skaber succes}

De interne ressourcer i kommunen kan også være til stor nytte. Næstved Kommune (DK) besluttede i 2014 at etablere Ressource City som en grøn byudviklingsklynge på den gamle papirfabrik Maglemølle i Næstved. Efter fire år er Ressource City en succes, hvilket især skyldes det gode samarbejde internt i kommunen og derudover den store opbakning fra Næstved Byråd og de mange øvrige interessenter. I Björneborg Kommune (FI) arbejdede de med udnyttelse af madspild hos kommunens skoler. De havde stor succes med at bringe ekspertise fra kommunens forskellige afdelinger sammen og arbejde for det fælles overordnede mål.

Inden der vedtages større cirkulære økonomiske tiltag, kan der med fordel gennemføres et pilotprojekt, som skaber grundlag for det videre arbejde og som giver medarbejderne et udgangspunkt for at udvikle egne kompetencer og erfaring med cirkulær økonomi i praksis. En væsentlig faktor for pilotprojekters succes er, at der er afsat tilstrækkelig medarbejdertid og -ressourcer hos de relevante medarbejdere og afdelinger til at drive projektet frem. Det giver størst tilfredsstillelse at arbejde med pilotprojekter, som tydeligt prioriteres i organisationen, og når ledelsen bakker op om projektet, også når vejen frem mod de ønskede resultater er bumpet. 
Den brede opbakning er nøglen til succes i Ronneby

Ronneby Kommune (SE) har siden 2011 fokuseret benhårdt på ressourceeffektivitet og cirkulære løsninger som en måde at styrke kommunens konkurrenceevne på. Ronnebys projekter har som udgangspunkt været centreret omkring byggeriet, og flere børnehaver er bygget ud fra en Cradle-to-Cradle-tankegang. I tilblivelsen af børnehaverne har der blandt andet været fokus på, at materialer til byggeriet var støjreducerende, sunde og fri for kemi. Desuden er belysning og andre elektriske installationer energieffektive og al elektricitet kommer fra vedvarende energi. Udenfor er der fokus på at øge biodiversiteten gennem beplantning, dyrkning af grøntsager og krydderurter samt kompostering. Derudover vægtes det højt, at både inde- og udemiljøerne motiverer børnene til bevægelse og leg i tæt kontakt med naturen.

Allerede fra starten var Ronneby opmærksomme på, at projekterne krævede bred opbakning fra alle de vigtigste interessenter, hvorfor man valgte at opstarte et nyt center i Ronneby, CEFUR, Center for Forskning og Udvikling, der skal bidrage til den cirkulære vision bl.a. ved at motivere kommunens mange forskellige interessenter. Ikke mindst erhvervslivet var afgørende for, at projektet kunne lykkes, og der blev derfor arbejdet hårdt på at skabe en god dialog og stærke partnerskaber med de lokale virksomheder. CEFUR gennemførte flere træningsforløb med lokale virksomheder og indgik i mindre "prestart"-projekter, der skulle geare erhvervslivet til at arbejde med cirkulære løsninger. Via det stærke fokus på dialog fik Ronneby skabt opbakning blandt virksomhederne, der hurtigt blev nogle af de vigtigste drivkræfter og fortalere for projektet. Igennem partnerskaber med andre kommuner og organisationer - både i og udenfor Sverige - fandt Ronneby desuden den viden og de færdigheder, der skulle bruges til at løfte arbejdet.

En anden afgørende interessentgruppe var den politiske ledelse. Der har fra starten været en god dialog med de involverede politikere, som har støttet op om projektet noget der har været helt essentielt for projektets succes: $A$ municipality is a top-down organisation. So if you don't get the attention from the politicians you will not get the budget and therefore couldn't do it - we had to tell the story to the management so that they would listen, forklarer kommunens enhedschef Johan Sandberg. Den politiske støtte har været godt hjulpet på vej af det ihærdige lokale erhvervsliv, der aktivt efterspurgte en bæredygtig vision for Ronneby, og tilsammen var det dét, der for alvor gav projektet vind under sejlene.

\section{Medarbejdere - hverdagens ambassadører}

Ronneby er i dag bredt anerkendt for sine cirkulære tiltag - også uden for Sveriges grænser - og har flere cirkulære projekter på dagsordenen, bl.a. i samarbejde med andre kommuner igennem et stort anlagt inter-europæisk projekt. Til trods for dette har en af Ronnebys største udfordringer været at gøre de cirkulære tiltag kendte blandt kommunens egne borgere: The project was mentioned in all the big papers and magazines - it is known by people in the business. Everybody heard about it - but if you ask people in the street, they do not know about Cradle-to-Cradle, circular economy or sustainability in Ronneby, forklarer Johan Sandberg. Derfor har kommunen lagt særlig vægt på at kommunikere ideerne og resultaterne ud til Ronnebys indbyggere og ikke mindst få startet en dialog omkring projektet. Blandt andet har man lavet et testlab, hvor folk 
kunne komme og lære mere om projekterne, Cradle-to-Cradle og cirkulær økonomi, og diskutere ønskerne til kommunen.

Udover at arbejde på dialogen med borgerne i Ronneby har kommunen også gjort en særlig indsats for at gøre medarbejderne til aktive medspillere i projektet. Blandt andet har personalet i de tre cirkulære børnehaver fået uddannelse i Cradle-to-Cradle og har været med under hele processen - fra udformningen af de konkrete ideer til evaluering af det færdige byggeri. Dette har givet en uventet bonus i form af øget begejstring og stolthed blandt pædagoger og andet personale i Ronnebys cirkulære børnehaver, og det smitter af på forældre og børn. På denne måde bliver medarbejderne ambassadører for kommunens vision og hjælper til at fange interessen hos borgerne, og det giver igen selvtillid og energi til nye projekter.

For Ronneby har succesen altså ligget i den brede opbakning til projektet, der er opbygget på tværs og i alle led af kommunen, og hvor interessenter har påvirket hinanden i en positiv vekselvirkning.

\subsection{Struktur og kultur}

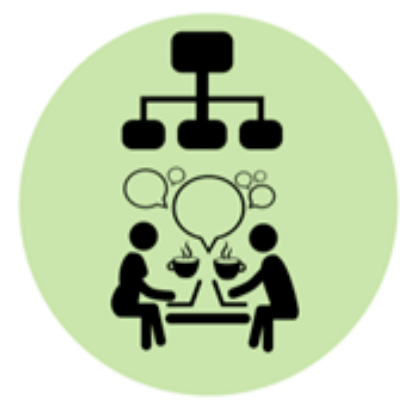

Strukturen betegner den formelle og uformelle opdeling og koordinering af arbejdsopgaver og ansvar, horisontalt og vertikalt. Kulturen binder kommunen sammen og kan have stor betydning for det cirkulære projekts sammenhængskræft og mulighed for succes. Kulturen kan ses som den samlede sum af alle medarbejdernes adfærd, med (den politiske) ledelse som den væsentligste kulturbærer.

I Aalborg Kommune (DK) er grønne indkøb ved at være en integreret del af kommunens indkøbspolitik. Dette bunder især i den politiske ledelsesbeslutning om at prioritere bæredygtighedshensyn i de kommunale udbud. Selvom den kulturelle forankring er nogenlunde på plads, kan den strukturelle opbygning af kommunens syv forvaltninger, med hver sin egen indkøbsafdeling og derudover den fælles indkøbsafdeling, være en udfordring for arbejdet med cirkulære tiltag på udbuds- og indkøbsområdet. Derudover er der udfordringer i, at det tager længere tid at lave de nye cirkulære udbud, hvorfor en dialog herom er vigtig i kommunen.

Case 31 
Kultur og struktur er på mange måder indbyrdes forbundne, idet en særlig kultur ofte fremelsker særlige kommunale strukturer og handlemønstre - og vise versa.

Cirkulær økonomi fordrer ofte strukturelle ændringer, da den gør op med den lineære opfattelse af producér-forbrug-smid-væk økonomi og i stedet fokuserer på, at produkter og råmaterialer genbruges, genanvendes og skaber mest mulig værdi i næste livscyklus.

Implementering af principperne for cirkulær økonomi vil ofte kræve nye arbejdsmetoder og tilgange, alt afhængig af den eksisterende struktur og kultur. Kommuner har typisk en strukturel opbygning, der følger ressortområder eller lovgivning på et område. Typisk kræver det cirkulære arbejde involvering af flere forskellige forvaltninger og ressortområder, idet optimering af ressourcekredsløb ikke holder sig inden for et enkelt område. Det kan være en udfordring at arbejde på tværs af den eksisterende struktur, idet eksempelvis en ressource som vand både kan adresseres $i$ et energiperspektiv, som affald (spildevand), og fra et hygiejneperspektiv.

Det kræver meget af de enkelte forvaltningsområder at tænke og arbejde på tværs, og ofte vil strukturen understøttes af budgetmæssige rammer, der er fordelt på enheder. Dette kan skabe en kultur, der favoriserer målopfyldelse inden for egne områder. I det cirkulære arbejde er kommunen derfor nødt til at gøre op med den traditionelle silotænkning og i stedet skabe en samarbejdsstruktur, der går på tværs af forvaltningerne og derudover også indbefatter virksomheder, borgere og civilsamfund $i$ arbejdet. Parterne skal i fællesskab løfte opgaven, for at kommunen kan nå i mål med det cirkulære arbejde, og det kræver, at det tværgående arbejde bliver synligt og får ledelsesmæssig opbakning, sådan at den samarbejdende kultur belønnes og understøttes, og at man i strukturen indbygger forbindelsesveje mellem enhederne.

ÆEndringer i kommunens struktur og kultur skal i høj grad bæres igennem af ledelsen, men kræver samtidig en vis grad af autonomi i arbejdsprocessen $i$ forbindelse med, at projektet drives frem og ændrer karakter. Det kræver altid flere ressourcer at gå udover det vante og indarbejde nye arbejdsgange. Derfor skal der ledelsesmæssigt fokuseres på, at denne omstilling er en investering.

\section{Fra byggeaffald til vækst}

Med projektet "Bedre Brug af Byggeaffald" ønskede Vejle Kommune (DK) at fremme bæredygtig ressourceoptimering og cirkulær økonomi gennem nye samarbejdsformer mellem private små og mellemstore virksomheder (SMV'er) og offentlige aktører. En af de helt svære opgaver var at få SMV'erne med om bord. I takt med at projektet skred frem, indså kommunen, at det var nødvendigt for kommunen at tilpasse sig, for at få projektet i mål. SMV'erne var ikke så ivrige som forventet, og derfor måtte kommunen selv tage førertrøjen på og søsætte projekter.

Den indledende projektbeskrivelse lagde op til en intern udveksling af materialer i byggebranchen, hvilket betød, at de måtte fastholde den silotænkning, som cirkulær økonomi ellers forsøger at gøre op med. Overtagelsen af byggematerialer kan være relevant for alle mulige produktionsvirksomheder - og altså ikke kun for andre aktører i byggebranchen. Det var en stor opgave at identificere potentielle virksomheder til at modtage byggeaffaldet, og mange af virksomhederne så ikke selv potentialet. Gennem en række oplysningskampagner (gå-hjem-møder og rådgivning) fik kommunen motiveret virksomhederne til arbejdet med cirkulær økonomi - en god påpegning af, at innovationsprojekter er fleksible i forhold til at definere problemstillingen og fokus, fordi det også er en læringsproces. 
Vejle Kommunes struktur understøtter innovative projekter, og medarbejderne har generelt modtaget projektet positivt, da der har været afsat ressourcer til arbejdet. I kommunen er de vant til at arbejde på tværs, da der er en general prioritering af midler til forskellige innovationsprojekter, bl.a. om cirkulær økonomi. Teknik- og miljøforvaltningen arbejder aktivt på at nedbryde siloer og understøtte tværfagligt samarbejde, men en fortsat fysisk barriere for samarbejder består i, at Teknik- og Miljøforvaltningen er placeret i en særskilt bygning væk fra de øvrige forvaltninger, hvilket giver færre "small-talks" på tværs af forvaltninger og begrænser spill-over effekter.

Case 17

\subsection{Systemer, data og digitalisering}

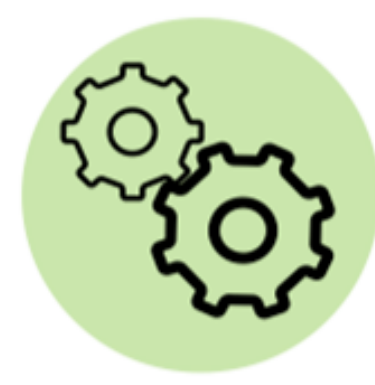

Systemer bidrager til at sikre effektiv styring af arbejdet og høj kvalitet i resultaterne. Systemer omfatter procedurer og retningslinjer for de væsentligste aktiviteter og en række øvrige metoder til bl.a. måling, datahåndtering mv. Der anvendes systemer hos alle kommuner, men der er forskel på hvilke og hvor omfattende.

Kommunerne oplever en øget digitalisering, og nye systemer for digitale løsninger vil i stigende grad blive en del af de offentlige kerneydelser i kommunerne. Samtidig kan kommunerne i højere grad bruge miljødata til at kvalificere og forberede beslutninger - det gælder både i forhold til at skabe baseline på de forskellige indsatser og måle på fremdrift. Data kan også fungere som innovationsdriver i forhold til at udvikle nye løsninger og services, der bidrager til at optimere materialestrømmene i kommunen. Der er mange nøgletal, der på forskellig vis benchmarker kommunerne. Disse data kan fremadrettet også benyttes af kommunen, så data i højere grad understøtter cirkulær økonomi-udvikling i de forskellige forvaltningsgrene. 
I Aalborg Kommune (DK) satte man sig for at udvikle et helt nyt og innovativt cirkulært udbud på skolemøbler, og det betød, at kommunen pludselig stod overfor en helt anderledes måde at tænke udbud på. For Birgitte Krebs Schleemann, Projektleder i Aalborg Kommune hersker der ingen tvivl om, at den største udfordring ved at omsætte ideerne om cirkulær økonomi i praksis var, at kommunen måtte genopfinde ellers eksisterende, og på mange måder fastforankrede, processer i udbudsafdelingen:

Vi lod virksomhederne byde på cases, normalt byder man ind med en lang række møbler, her der lod vi dem løse fire konkrete cases. Så det her med at skrue et udbud helt anderledes sammen - det var noget af en mundfuld for os alle - også udbudskonsulenten.

I Aalborg valgte man at lægge arm med en helt ny måde at betragte det kommunale udbud og indkøb på, også selvom dette krævede en ny tankegang og øgede ressourcer fra både medarbejdere og ledelse. De nye processer gav heldigvis pote i form af et innovativt cirkulært udbud, der har medført at udbudsprocessen har fået en ekstra dimension, og som har givet medarbejdere og ledelse en uvurderlig erfaring til brug for efterfølgende cirkulære udbud i kommunen.

Case 31

Ved at koble flere enheder sammen via sensorer, chips og aflæsningssystemer kan kommunen opsamle værdifulde data og dermed optimere og tilpasse systemer på baggrund af den nye dataviden, bl.a. på affaldsområdet. Ved at udnytte data fra nøglekort, chips, vægte og sensorer kan der genereres viden om brugeradfærd, tømninger, vægtindhold, fyldningsniveau m.m., der kan effektivisere kørslen og indsamlingsmetoderne, optimere det eksisterende indsamlingsmateriel, visualisere problematiske områder grafisk, lave elektronisk feedback til borgerne og skræddersy sorteringsløsninger og kommunikationen med borgerne om deres genbrugs- og genanvendelsesindsats.

Et system kan også være af mere lavpraktisk art, men her er det alligevel mindst lige så vigtigt at gøre sig tanker om hvilke procedurer, der kan være gavnlige at implementere og som for eksempel kan være afgørende for effektiviteten og sammenhængskraften i en projektgruppe. Et stort anlagt projekt med mange (også udefrakommende) interessenter og flere medarbejdere fra forskellige afdelinger med hver deres arbejdsmetode og -kultur kræver for eksempel en særlig opmærksomhed og et fokus på at få opbygget gode procedurer for mødeplanlægning og opfølgning på møder.

\subsubsection{Nye cirkulære tiltag kræver nye systemer}

Det er vigtigt at finde den rette balance i antallet af systemer, da for meget system kan føre til ansvarsfralæggelse hos medarbejderne og rigide arbejdsformer, mens for lidt gør det vanskeligt at opnå en effektiv gennemførelse af indsatsen. Det handler mere om kvaliteten i systemerne end om antallet, da de rette systemer kan frigøre ressourcer til vigtigere opgaver.

Den cirkulære tankegang byder for mange kommuner på et helt nyt mind-set og kan føre til, at man må genoverveje de hidtidige arbejdsgange og systemer. Det kræver ofte en vis overvindelse at skulle modificere forankrede systemer og processer, men det kan være særdeles fremmende for projektets kvalitet. Modsat kan et system, der ikke passer til den cirkulære udfordring, være en barriere for gode resultater. 
I Holbæk Kommune (DK) manglede man i projektet omkring recirkulering af byggeaffald generelt mere viden omkring, hvilke modtagere der kunne findes af de forskellige fraktioner fra bygningernes nedrivning. På grund af projektlederen, teamet og entreprenørens forudgående undersøgelse af både byggeriets sammensætning og markedet kunne man afsætte hele 97,5 procent af den gamle skolebygning i takt med nedrivningen. Ved at være tidligt ude og have helhedstanken med fra start, fik man således kortlagt, miljøsaneret og genanvendt en række materialer, så som metal, glas, beton, tagpap, isolering, træ, sanitet, gips og elektronik. Identificeret problemaffald, som for eksempel asbest, fuger, forurenet træ, klinker og linoleum blev samtidig bortskaffet på forsvarlig vis.

Det var dog et stort arbejde at undersøge mulige aftagere af de forskellige fraktioner, og en generel oversigt over markedet kan derfor være til stor hjælp i det cirkulære arbejde.

Case 17

Kommunerne administrerer generelt en stor bygningsmasse, og der kan være sund fornuft i at få identificeret alle de bygninger, som kommunen råder over, kortlægge det ressourcemæssige potentiale, se på udnyttelsesgraden af bygningerne og systematisere planlægningen af anvendelsen. Når der rives ned, kan man opnå større afsætningssikkerhed ved at anvende flere afsætningskanaler og afdække afsætningsmuligheder både lokalt, nationalt, de nordiske lande imellem, eller i EU. I dag mangler der tit en kobling af genbrug eller genanvendelse - fra nedrivning og renovering, til hvem der kan aftage materialerne og afsætte dem til bæredygtige byggeprojekter ${ }^{9}$.

Projektet Gen Byg Data, der blev gennemført i tæt samspil mellem Skive Kommune (DK) og andre partnere, har skabt en åben platform Dansk Genbyg ${ }^{10}$, der i dag drives 100 procent kommercielt. Platformen tilbyder data om fremtidige forventede tilgængelige materialer og ressourcer fra eksisterende bygninger samt om allerede tilgængelige genanvendelige materialer og ressourcer - og både kommuner og virksomheder har mulighed for at købe og sælge genbrugsmaterialer. Portalen skitserer, hvordan data om byggematerialer i nedbrydningshuse kan anvendes til at gøre materialerne genanvendelige og salgbare.

Systemer til beregning af Total Cost of Ownership (TCO) kan bidrage til at sætte den cirkulære dagsorden i kommunen, idet man ved beregningen af et produkts pris medregner alle omkostninger, der er forbundet med produktets drift og brug i hele levetiden - herunder forbrug af hjælpestoffer og energi samt indirekte omkostninger såsom vedligeholdelse og bortskaffelse. I en kommunal virkelighed giver et sådan totaløkonomisk perspektiv bedre mening end blot at betragte anskaffelsesprisen, og der er mange eksempler på, at TCO kan gavne både pengepungen og miljøet. Der findes i de nordiske lande en række offentlige websteder med råd, vejledning og gode eksempler på TCO, herunder hos Statens og Kommunernes Indkøbsservice (DK).

Mange kommuner oplever, at afdelinger flytter, lukker ned eller lægges sammen. I Växjö (SE) kiggede man nærmere på, hvad der egentlig skete med de tilbageblevne

\footnotetext{
9 Kommunernes Landsforening (2016): Den cirkulære kommune - Inspirationskatalog.

${ }^{10}$ https://genbyg.dk/?gclid=CjwKCAiAiJPkBRAuEiwAEDXZZfiStM7wgDOdjDIk-mUScxQGofFLZz-a_od-

VeXuiwTgoPOI7osziqxoCNhcOAvD_BwE
} 
møbler, når kommunale bygninger blev forladt. Ofte blev de stående eller smidt ud, og kommunen fandt både et økonomisk og miljømæssigt forbedringspotentiale i oprette systemet Möbelcirkeln for møbler, der er til rådighed $\mathrm{i}$ kommunen. Fra nedlagte afdelinger indsamles møblerne til et lager og formidles på en hjemmeside, hvor kommunens afdelinger gratis kan vælge genbrugsmøbler. Dette system er især skoler og børnehaver begejstrede for, idet budgettet til nye møbler ofte er småt.

\section{Genbrugssystem som projektmål}

Da Eskildstuna (SE) skulle til at oprette endnu et genbrugscenter, ønskede de større fokus på direkte genbrug af det indleverede affald. Derfor blev der i forbindelse med genbrugscenteret bygget et shoppingcenter, hvor butikkerne udelukkende forhandler med genbrugte produkter fra genbrugscenteret eller med produkter de selv har fremstillet. Dermed kommer genbrugsmuligheden i system. Når kommunens borgerne tager turen til genbrugscenteret med deres affald og gamle sager, er der mulighed for at frasortere stadig funktionelle produkter og aflevere dem på en drop-off i centeret. Disse produkter bliver derefter givet til de butikker, som istandsætter og reparerer hvis det er nødvendigt.

\section{Se mere på ReTuna ${ }^{11}$}

\subsection{Kommunikation}

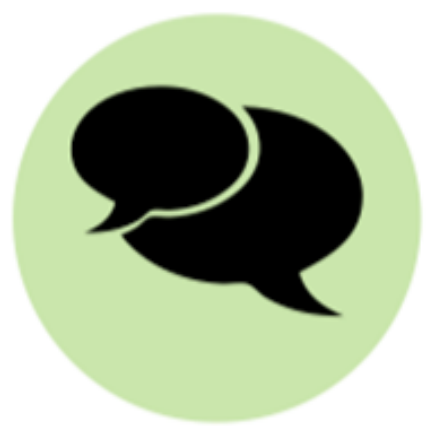

\subsubsection{Intern kommunikation}

God kommunikation internt i et projektteam eller i en organisation kan sikre, at alle har samme viden til rådighed og skabe fælles forståelse for projektets mål, aktiviteter og retning. Samtidig har det en inddragende effekt, og giver aktører og medarbejdere mulighed for at tage medansvar. Og så forebygger den gode vidensdeling, at viden går tabt, hvis en medarbejder stopper undervejs i projektet.

\footnotetext{
${ }^{11}$ https://www.retuna.se/
} 
Mange kommuner gør god brug af deres interne kommunikationsgange, men hvis fornemmelsen er, at det kommunale intranet snarere end en vidensportal mere er blevet et statisk arkiv, der ikke bliver opdateret, og hvor information ofte overses, kan der være behov for nye måder at kommunikere på.

I Kupio (FI) anvender man i arbejdet med cirkulær økonomi en intern kommunikationsplatform, der er en del af kommunens intranet, og som holder medarbejderne opdaterede på igangværende projekter. Systemet giver medarbejderne et godt overblik over, hvad der sker i kommunen, og skaber både medarbejderengagement og tilhørsforhold til de cirkulære projekter. Det kan desuden hjælpe til en konkret optimering af de projekter, der er i gang, ved at kollegaer, der ellers ikke er direkte involveret i projektet, kan tilføre en ny vinkel, som ellers ikke var kommet frem.

I Helsinki (FI) har man valgt et kommunikationsværktøj, der skaber engagement og letter kommunikationsgangene for medarbejdere tilknyttet et specifikt projekt. Værktøjet giver en klar struktur på informationen, der derved lettere spredes mellem de implicerede medarbejdere (end e-mails, der ofte forsvinder i indbakkens skov af korrespondance). Samtidig giver det et dynamisk flow i en verserende diskussion, idet alle nemt og hurtigt kan blive opdateret på forløbet og supplere med egne input.

\subsubsection{Ekstern kommunikation}

Kommunen er ansvarlige for at forvalte de materialer og ressourcer, som indsamles fra borgerne, og skal sikre højest mulig genanvendelse. Kvaliteten af det affald, borgerne udsorterer, har stor betydning - jo bedre sorteret desto højere pris og bedre miljøperformance. Kontinuerlig kommunikation, feedback og involvering er afgørende for sorteringsindsatsen, og den sociale anerkendelse kan være en afgørende faktor for succes. Alle borgere skal kunne se deres daglige sorteringsindsats som nyttig, og kommunen kan gå forrest og med målrettet kommunikation styrke ressourcebevidst adfærd hos medarbejderne i forvaltningen, på skoler, institutioner osv.

Vigtigheden i at kommunikationen i et projekt forløber godt og dermed påvirker projektet positivt, oplevede de i Pori Kommune (FI) i deres bestræbelser på at mindske madspildet i kommunens skoler gennem donationer af overskydende mad. I første omgang mødte projektet stor skepsis blandt kommunens ansatte og partnere, som ikke så fordelene ved at ændre de vante arbejdsgange. Gennem afholdelse af arrangementer undervejs og kontinuerlige møder med vigtige partnere, sikrede kommunen, at konceptet og fordelene derved blev kommunikeret ud, så partnere og medarbejdere opnåede en større forståelse og anerkendelse for projektet.

Case 11

I Asker Kommune (NO) har man været meget bevidste om, at målgruppen for deres cirkulære projekt krævede en særlig kommunikationsindsats. Projektets største udfordring var at få folk engagerede i at få udtjent tøj i recirkulation og derudover minimere forbruget af tekstiler. Asker kommune var bevidste om, at borgernes adfærdsmønstre hænger nøje sammen med nutidens forbrugsmønster, høj levestandard etc., og at det er en adfærd, der kan være svær at ændre. Derfor har kommunen gjort meget ud af at 
undersøge, hvilke kommunikative værktøjer der ville fungere bedst for projektet, og man nåede frem til, at positive virkemidler som kampagner med kant og humor ${ }^{12}$ er en god måde at få budskabet ud til borgerne. Og selvom det har krævet flere ressourcer, end Asker kommune normalt bruger på den eksterne kommunikation, har det været givet godt ud i bestræbelserne på at få den cirkulære tankegang spredt i kommunen.

\section{Dialogen som løftestang}

I Jyväskylä (FI) er projektet "Resource Wisdom" støttet af alle partier i byrådet og gennemført i åben dialog med kommunens medarbejdere og andre interessenter: Vi havde en løbende åben linje for ideer til at forbedre vores arbejde.

Dette gav ikke kun nye vinkler til projektet og højnede muligheden for succes, men var samtidig med til at motivere medarbejderne og øge engagementet for projektet som helhed.

Kommunen indsamler løbende ideer fra medarbejdere og borgere og har indtil videre gennemført ti forskellige pilotprojekter baseret på ideer direkte fra borgerne. Næste kald for nye ideer vil blive åbnet i løbet af 2019.

Case 4

\subsection{Partnerskaber}

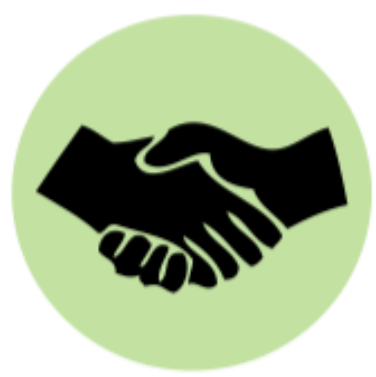

Partnerskaber kan sikre lokal forankring med virksomheder og uddannelses- og forskningsinstitutioner, som kan bidrage med andre kompetencer, end kommunen selv har og være med til at virkeliggøre kommunens vision. Samtidig kan kommunen være en drivkraft for særligt små og mellemstore virksomheders arbejde med cirkulær økonomi - både som en stor potentiel kunde og fordi kommunen har en central rolle og viden på bl.a. forsyningsområdet. Partnerskaber med fokus på cirkulær økonomi kan derfor være med til at sikre bedre miljø, lavere omkostninger og øget forsyningssikkerhed hos virksomhederne.

Projekter involverer ofte flere forskellige aktører, og det er vigtigt at oprette gode forbindelser til de relevante og primære aktører gennem inddragende aktiviteter. Der kan skabes velfungerende cirkulære værdikæder mellem de offentlige og private aktører ved

${ }_{12} \mathrm{Se}$ "Alt har verdi»-kampanje", hvor Asker kommune fik udviklet store plakater til busser etc. http://gullblyanten.no/media/uploads/96og/31479-9701f-archive.pdf 
at samarbejde på tværs gennem partnerskaber. Det forudsætter en analyse af værdikæden, hvor man kan drøfte roller og ansvarsfordeling mellem kommunen og andre aktører i partnerskabet, herunder virksomheder, forsyningsselskaber og organisationer.

\section{Partnerskaber er vejen frem for cirkulær økonomi}

Ressource City er en innovations-, videns- og inspirationsklynge inden for cirkulær økonomi, som arbejder projektorienteret i tæt samarbejde med en række partnere, der består af andre offentlige aktører, uddannelsesinstitutioner og virksomheder. Ressource City arbejder også for, at erhvervslivet udnytter det store forretningsmæssige potentiale inden for cirkulær økonomi, og dermed skaber nye grønne virksomheder og jobs.

Netværk og partnerskaber mellem de mange aktører og interessenter, som arbejder med cirkulær økonomi, har været væsentlig for Ressource Citys succes. Derudover er der stolthed over og stort engagement for Ressource City blandt chefer og medarbejdere i Næstved Kommune.

Case 29

Det er ofte via partnerskaber, at de succesfulde projekter opstår. I Göteborg kommune (SE) har man med projektet om Alelyckan Genbrugspark formået at samle partnere med fælles interesse for genbrug og reparation. Et cirkulært koncept med samling af genbrugsbutikker og reparatører ved kommunens genbrugscenter styrker direkte genbrug. Yderligere afholdes der regelmæssigt workshops og debatarrangementer med borgerne for at få deres input og inddrage inddrage dem i parkens arbejde. Succesen har medført, at parken har omkring 400 besøgende dagligt.

Når man giver stor medindflydelse til værdiskabende aktører, får man samtidig skabt medansvar for projektet. Ved at tydeliggøre fordele og værdi, som projektet kan skabe for aktørerne, er det lettere at inddrage dem og få dem til at støtte op om projektets vision. Det er også vigtigt at etablere systematisk erfaringsudveksling med andre kommuner, der arbejder med lignende projekter, idet kommunerne her kan optræde som aktive medspillere i de cirkulære tiltag. Desuden er det gavnligt at være opmærksom på samarbejdsprojekter, der allerede er færdiggjort, og som kan give inspiration og gode erfaringer til arbejdet. Oversigten over nordiske tiltag på cirkulær økonomi i det følgende kapitel, kan give gode input til arbejdet.

Det kommunale affaldsselskab ROAF står for indsamling af affald i Nedre Romerik, som omfatter flere kommuner i Østnorge. Hos ROAF indsamles affaldet i fraktioner og videresælges til forskellige aftagere i Europa, der omdanner affaldet til nye ressourcer. Værdien af affaldet stiger, jo renere fraktioner det er tale om og jo lettere materialerne er at genanvende. For at opnå en højere renhed og større genanvendelse meldte ROAF sig ind i en emballageforening for at biddrage til at optimere emballagedesign i forhold til genanvendelse. Det strategiske partnerskab og vidensdeling gennem hele værdikæden viste sig yderst værdifuldt for både producenter, affaldsselskaber, aftagere og ikke mindst den cirkulære udvikling.

\section{Case 13}




\section{Nordiske eksempler på cirkulær økonomi i kommuner}

I dette kapitel er samlet en række cases fra de nordiske kommuner med eksempler på cirkulære tiltag. Casene er opdelt i fire temaer:

1) Ressourcer og forsyning,

2) Byggeri og anlæg,

3) Erhvervsudvikling og

4) Indkøb og udbud.

Casene dækker Norge, Sverige Finland og Danmark samt et enkelt eksempel fra Grønland. Casene er praksisnære og viser den brede spændvidde i cirkulære tiltag i de nordiske kommuner.

Casene viser eksempler med nye og bedre produkter og tjenester til forebyggelse af affald, genanvendelse af produkter, udstyr og byggematerialer (på kommerciel eller social basis), recirkulation af materialer, stoffer eller energi, rådgivning, uddannelse og forretningsudvikling, mens andre har fokus på strategier og modeller.

Der findes mange flere nordiske eksempler på cirkulære tiltag, der kunne være medtaget i denne liste. Der er dermed langt fra tale om en udtømmende liste, men et udpluk af relevante cases til inspiration.

Casene er udvalgt fra en bruttoliste på 70 cases i alt. Der er udarbejdet en overordnet mapping med tilhørende note om, hvordan 40 udvalgte cases kan understøtte de forskellige elementer i guiden. Det er for hver case oversigtligt noteret, om casen bidrager stærkt til de tre bæredygtighedsdimensioner - økonomi, socialt og miljø - idet alle cases $i$ et eller andet omfang kan tale ind til de tre bæredygtighedsdimensioner. Det er ikke søgt at analysere potentialet i de forskellige eksempler, hvilket dog kunne være ønskeligt i et senere projekt i forhold både til de enkelte lande og på tværs af Norden.

Alle cases har miljø som parameter, hvor der typisk er fokus på genbrug, genanvendelse, cirkulære materialestrømme, $\mathrm{CO}_{2}$ - besparelser eller at begrænse farlige stoffer.

31 af de 40 cases har fokus på den sociale dimension forstået som enten socialøkonomiske arbejdspladser, samskabelse og samarbejde på tværs for eksempel med borgere, egne institutioner, forsyninger, virksomheder og forskningsinstitutioner samt samarbejder på tværs af kommuner.

28 af de 40 cases har fokus på økonomi. Dette dækker typisk nye markeder, sparede eller reducerede omkostninger samt ofte nytænkning og elementer af innovation.

Der er gennemført 23 interviews med udvalgte kommuner. 
Tabel 1: Ressourcer og forsyning

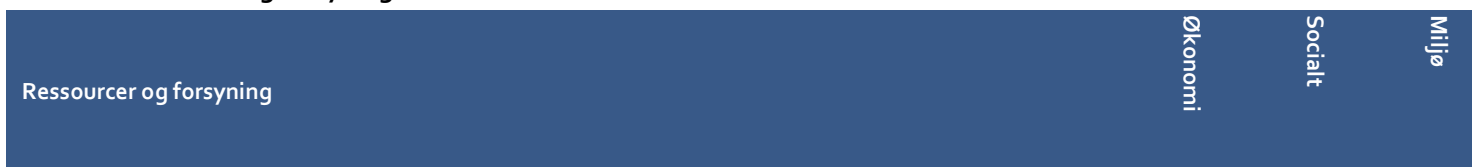

1. Affaldsselskaber underviser skoleklasser i affaldshåndtering og recirkulering, Norge

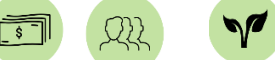

Flere affaldsselskaber i Norge underviser skoleklasser i affaldshåndtering, hvilket øger børns bevidsthed omkring, hvorfor vi kildesorterer. Forskning viser, at en tidlig bevidsthed udvikler børns adfærd i forhold til korrekt affaldshåndtering, hvilket desuden har vist sig at smitte af på forældrenes adfærd. Det gælder for kommunerne om at påtage sig en aktiv rolle, når det handler om at informere borgerne.

Læs mere om affaldsselskabernes undervisning, se tabelnote (1).

2. Ambassadører for bæredygtighed i femte klasse, Finland

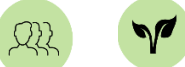

Miljøteamet i Borgå Kommune i Finland har udviklet et koncept, der sætter fokus på miljøvenlig adfærd hos børn og familier. Konceptet forløber under National Energy Week og går ud på, at elever i femte klasse på Borgås grundskoler får udleveret et miljøpas, hvor de skal notere deres miljøvenlige adfærd. Her skal de forholde sig til genbrug, energibesparelser og forbrug. Under temaugen får eleverne informationer, der peger på måder at træffe nogle valg i hverdagen, som minimerer klimabelastningen. Konceptet inddrager forældrene ved, at de skal skrive under i et miljøpas, før det afleveres til deres skolelærer. Læs mere om projektet via tabelnote (2).

3. Bystrategi: "Ressource wise", Finland

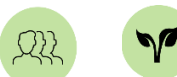

I Finland har Kuopio Kommune fundet frem til, at ressourceklogskab er et hovedmål i deres byudviklingsstrategi for at sikre borgerne det gode liv. Strategien er blevet udviklet under inddragelse af civilsamfund og erhvervslivet. Der er udviklet delmål, som er konkretiseret i et program, der strækker sig over flere år. Det fremhæves, at byen skal have smart mobilitet, være energieffektive og anvende vedvarende energi, anvende cirkulær økonomi og være ressourceoptimerende. Læs mere om Resource wisdom and circular economy, se tabelnote (3).

4. En ressourcebesparende driftsmodel for byudvikling, Finland

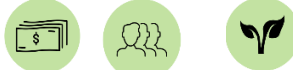

I Finland har Jyväskylä Kommune og den statslige innovationsfond, Sitra, i perioden 2013-2015 udviklet en driftsmodel for byer og kommuner, som skal hjælpe dem til at fremme bæredygtig brug af naturressourcer. Modellen blev i foråret 2015 testet gennem et pilotprojekt i byerne Forssa, Lappeenranta og Turku i Finland, og på baggrund heraf, er der udarbejdet en "ressource wisdom road map" for hver enkelt by. Dette blev grundstenen til et netværk af finske bæredygtige byer og kommuner (FISU-netværket), hvilket oprindeligt er medlemmerne: Forssa, Jyväskylä, Lappeenranta og Turku, som udarbejder "ressourcevisdomsindsatser". FISU er åbent for alle byer og kommuner med interesse for bæredygtig udvikling. Læs mere om The Model of Ressource Wisdom, se tabelnote (4). Læs mere om projektet Jyväskylä gør brug af ressourcebesparende model, se tabelnote (4.1).

\section{Et energiproducerende rensningsanlæg, Danmark}

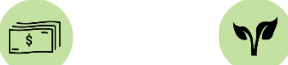

I Aarhus Kommune er det kommunalt ejede Marselisborg Renseanlæg blevet energiproducerende - og producerer endda 50 procent mere energi end det forbruger. Den overskydende energi giver grøn el og varme til borgerne i Aarhus Kommune. Rensningsanlægget udvinder biogas og fosfor fra spildevandsslammet, som derefter afbrændes og bliver til energi. Om nogle år forudses det, at Marselisborg Rensningsanlæg har for lille kapacitet i forhold til antal borgere i Aarhus Kommune, hvorfor det skal udbygges. Virksomheden Aarhus Vand samler eksperter og iværksættere til at indgå i partnerskaber for at løse innovationsudfordringer i forbindelse med anlæggelsen af Marselisborg Ressourceanlæg, som kommer til at stå for rensning af al spildevand i Aarhus Kommune. Det nye anlæg har til formål at sikre et optimalt vandmiljø; ved udnyttelse af ressourcerne i spildevandet nedsættes omkostningen til spildevandsrensning ved salg af energi, og derudover reduceres $\mathrm{CO}_{2}$-udledningen. Denne renseanlægsmodel er blot én ud af flere i Danmark. Læs mere om projektet Renseanlæg bliver verdens mest ressourceeffektive, se tabelnote (5). Læs om projektet på Aarhus Vands internationale hjemmeside: Aarhus Rewater, se tabelnote (5.1). Se idékataloget Fremtidens energiproducerende renseanlæg, se tabelnote (5.2).

6. Fra mad til muld, Grønland

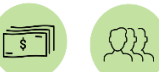

I Grønland er der blevet sat gang i flere projekter med fokus på at få sorteret glas, dåser og organisk affald ud af husholdningsaffaldet. I kommunen Qeqqata blev affaldssortering i 2014 en nødvendighed, da forbrændingsanlægget i byen Sisimiut ikke længere kunne følge med mængden af brændbart affald fra byen. I Sisimiut har et pilotprojekt for en række virksomheder, institutioner og en-boligblok først og fremmest haft til formål at udsortere madaffaldet fra det øvrige husholdningsaffald. Alle beboere fik alle udleveret beholdere og vejledning til sortering af madaffald. Det indsamlede madaffald blev herefter komposteret. Det tager omkring 8 uger at omdanne madaffald til muldjord, som er en mangelvare i Grøndland. Læs mere om projektet på s. 38 i udgivelsen 'CSR i Grønland 2015 - Viden, cases og inspiration' via linket i tabelnoten (6). 


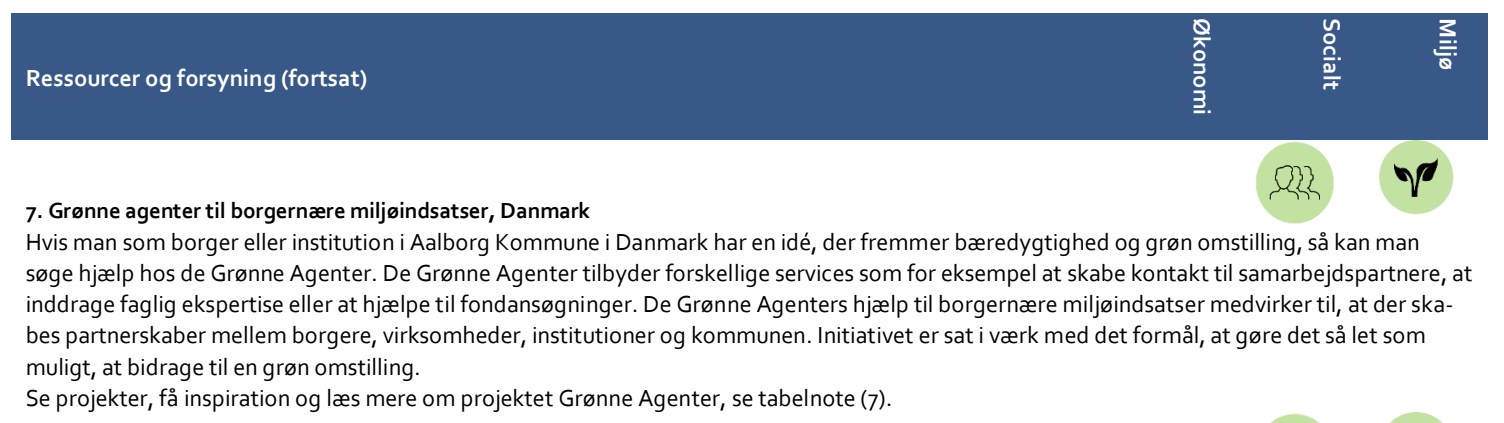

8. Kommunal konkurrence om affaldsreduktion, Sverige

Virksomheder, foreninger og borgere har i Sverige konkurreret om at vinde prisen for den bedste affaldsbesparende idé internt - men også mellem virksomheder og kommuner. Göteborg Kommune har eksempelvis reduceret deres affald ved at inddrage plejehjemmet Sekelbo med fokus på reduktionen af madspild. Dette er lykkedes ved et dedikeret personale, der dagligt melder tilbage til køkkenet om plejebeboernes ønsker til mad samt mængden af mad, der ikke er blevet spist. Det har resulteret i, at madspildet er reduceret med 23 procent og restaffaldet med 10 procent, samt at miljøet er blevet skånet for seks tons $\mathrm{CO}_{2}$. Læs mere om projektet i Göteborg på s. 6-7 i udgivelsen "Kommunerna visar vägen för mindre avfall" via linket i tabelnoten (8). Der er udarbejdet en vejledning og en checkliste til forebyggelse af affald på plejehjem. Vejledningen kan findes via linket i tabelnoten (8.1). Checklisten kan findes via linket i tabelnoten (8.2).

9. Kommunalt samarbejde om etablering af anlæg til håndtering af bioaffald, Norge

Der er flere eksempler i Norge, hvor kommunerne samarbejder om etablering af større anlæg for håndtering af bioaffald. Dette gælder "Den magiske fabrikken" i Vestfold, "Ecopro" i Trøndelag, "IVAR" i Rogaland og "Romerike Biogassanlegg". Anlæggene omdanner bioaffaldet til biobrændsel, hvilket fremmer miljøvenlige køretøjer. Manglen på infrastruktur til salg af biogas gør det nødvendigt at skabe nye markeder. Det kan eksempelvis være langsigtede leveringsaftaler til busselskaber. Sådanne initiativer driver nye kredsløb og markeder ind i en cirkulær økonomi. Læs mere om samarbejdet via linket i tabelnoten (9).

10. Miljøambassadørordning, Danmark

Frederiksberg Kommune i Danmark har iværksat en miljøambassadørordning, som handler om, at hver af kommunens 200 institutioner har en fast miljøambassadør. Miljøambassadørene har ansvaret for at igangsætte og vedholde indsatser under kommunens miljøpolitik, hvilket blandt andet omfatter affaldssortering, energioptimering og indeklima. Miljøambassadørordningen er en metode til at forankre miljøtiltag og tilpasse dem, så de passer til den lokale kultur. Dette er netop muligt, da hver miljøambassadør har forståelse og naturlig tilknytning til den pågældende institution, og derved kan motivere lokalsamfundet til at yde en indsats. Lindevangskolen på Frederiksberg er et eksempel på en institution, hvor miljøambassadørordningen har givet økonomisk gevinst. Ved at skærpe adgangsforholdene til skolens affaldsbeholdere og tilpasse kapaciteten til udsortering af genanvendeligt affald, bruger skolen omkring 64 procent færre udgifter på deres affaldsbehandling. Læs mere om miljøambassadørordningen fra s. 22 i udgivelsen 'Mere genanvendelse i den kommunale servicesektor' Frederiksbergs Miljøambassadørordning se tabelnote (10).

11. Næringsbanken - Madspild på skoler bliver til "madhjælp" for udsatte, Finland Der eksisterer et stort madspild på mange skoler, og det har den finske kommune Björnstad/Pori valgt at adressere gennem et projekt, hvor madspild bliver til "madhjælp" for udsatte - et koncept der kaldes "næringsbanken". Konceptet går ud på, at overskydende mad fra kommunens skoler bringes ud til foreninger, der hjælper arbejdsløse og andre økonomisk dårligt stillede personer.

Konceptet skal bidrage til, at sætte fokus på den totale mængde madspild fra skolerne, at arbejdsløse unge får job som chauffører for madhjælpen, at hjælpe økonomisk udsatte grupper, og at sikre økonomiske besparelser for kommunen. Resterende madaffald anvendes til biobrændstof. Læs mere om projektet se tabelnote (14).

12. Ravita-modellen - Genvinding af fosfor fra renset spildevand, Finland

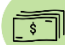

Helsingforsregionens Miljötjänster (HRM) er en kommunalt ejet organisation i Finland, som sørger for vandforsyning, affaldshåndtering, samt at producere publikationer om storbyområdet og miljøet. HRM har udviklet en fremgangsmåde til genvinding af fosfor fra det rensede spildevand. Metoden kaldes Ravita-proces, og her bliver fosfor til fosforsyre, hvilket gør det muligt at udnytte fosfor i flere forskellige industrielle processer og i gødningsproduktion. Metoden er i produktudviklingsfasen, men vil egne sig til forskellige typer af behandlingsanlæg. Målet er, at teknologien skal spredes ud til alle finske kommuner, så Finland kan opnå en cirkulation af fosfor.

Læs mere om projektet via linket i tabelnoten (12). 
13. Samarbejde mellem affaldsselskaber og uddannelsessektoren styrker uddannelsesforløb, Norge

Flere kommunaltejede affaldsselskaber i Norge har indgået samarbejde med universiteter og højskoler om at udvikle uddannelsesforløb, der giver viden om- og værktøjer til anvendelsen af cirkulær økonomi. Dette gælder eksempelvis et samarbejde mellem Samarbejdet i Midt-Norge (SESAM) og Norges Teknisk-Naturvitenskapelige Universitet (NTNU). Derudover samarbejder renovationsselskabet BIR A/S med Norges Handelshøyskole (NHH) for at klarlægge forudsætningerne for cirkulær økonomi. Desuden samarbejder det internationale affaldsselskab ROAF (Romerike Avfallsforedling IKS) med Institutt for energiteknikk omkring udbygning af et genanvendelsescenter baseret på bæredygtige materialer. Læs mere om samarbejdet via linket i tabelnoten (13).

14. Sesammen - Et strategisk samarbejde, Norge

SeSammen er et samarbejde mellem kommuner og affaldsselskaber i Norge. Målet med samarbejdet er at udføre en samfundsansvarlig kredsløbsbaseret ressourceudnyttelse, som lever op til affaldshierarkiet. SeSammen består af følgende aktører: Envina, Renholdsverket, Innherred Renovasjon, Midtre Namdal Avfallsselskap, Fjellregionene Interkommunale Avfallsselskap, Fosen Renovasjon, Hamos Forvaltning og Steinkjer Kommune. SeSammen er vurderet til at være afgørende for en cirkulær omstilling. Strategisk samarbejde mellem flere inter-kommunale virksomheder og en kommune muliggør stordriftsfordele, såsom større anlægsinvesteringer og harmoni mellem sorteringsordninger. Læs mere om samarbejdet via linket $i$ tabelnoten (11).

15. Socialøkonomi skaber mere genbrug, Danmark

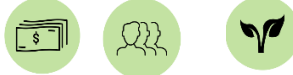

GOGGS er en dansk socialøkonomisk virksomhed, som blev dannet i et samarbejde mellem Randers Kommunes afdeling for Bo- og Erhvervstræning, Jysk Børneforsorg og Thor Trans A/S. GOGGS har til formål at skabe rummelige arbejdspladser for medborgere med nedsat erhvervsevne og samtidig øge mængden af genbrug. Konceptet går ud på, at de ansatte indsamler og istandsætter genbrugelige ting, som er indleveret på genbrugspladsen i Randers, for derefter at fragte tingene til en ny genbrugsplads, hvor de bliver solgt. Målet er, at mængden af affald nedbringes med op mod 100 tons årligt. GOGGS beskæftiger 15-20 personer, men forventer på sigt at beskæftige omkring 75 medarbejdere. Læs mere om projektet GOGGS styrker genbrug og giver flere rummelige arbejdspladser, se tabelnote (15).

(1) http://www.ks.no/fagomrader/samfunn-og-demokrati/samferdsel-plan-og-miljo/sirkular-okonomi/gode-eksempler/tidliginformasjon-til-innbyggerne/

(2) https://www.sitra.fi/sv/cases/skolans-pass-satter-konsumtionsvanorna-skick/

(3) https://www.kuopio.fi/fa/resurssiviisaus-ja-kiertotalous

(4) https://www.sitra.fi/en/articles/finnish-cities-engage-residents-sustainable-development/

(4.1) https://www.ubc-sustainable.net/news/city-jyvprocentC3procent $A_{4}$ skylprocentC 3 procent $A_{4}$-finland-bringing-wise-useresources-closer-its-citizensprocentE2procent8oprocent99-daily-life

(5) https://www.aarhusvand.dk/om-os/nyheder/aarhusiansk-renseanlag-bliver-verdens-mest-ressourceeffektive/

(5.1) https://www.aarhusvand.dk/en/international/new_solutions/aarhus-rewater/aarhus-rewater/

(5.2) https://www.aarhusvand.dk/globalassets/filer/projekter/fremtidens-spildevand/idekatalog-fremtidens-renseanlag.pdf

(6) http://ny.csr.gl/Portals/o/vedhprocentC3procentA6ftedeprocent2ofiler/Publikationer/220115procent2oFINAL_CSRpro-

cent2omagasin_dk.pdf

(7) http://www.grønneagenter.dk/

(8) https://goteborg.se/wps/wcm/connect/e3d90162-ebd3-4858-afc5-438e729obo4d/FprocentC3procentB6rebygg+avfall+pprocent $C_{3}$ procent $\mathrm{A}_{5}$ +procent $\mathrm{C}_{3}$ procent $\mathrm{A}_{4}$ ldreboendet.pdf?MOD=AJPERES

(8.1) https://goteborg.se/wps/wcm/connect/672ag965-5a2f-4463-b734-87e88d4cc579/FprocentC3procentB6rebygg+avfall+pprocent $C_{3}$ procent $A_{5}+$ procent $C_{3}$ procent $A_{4}$ Idreboendet+checklista.pdf?MOD=AJPERES

(8.2) https://www.avfallsverige.se/fileadmin/user_upload/Nyheter/Bilaga_Dagens_Samhalle_180607.pdf

(9) http://www.ks.no/fagomrader/samfunn-og-demokrati/samferdsel-plan-og-miljo/sirkular-okonomi/gode-eksempler/bioavfall/

(10) https://www2.mst.dk/Udgiv/publikationer/2015/og/978-87-93352-63-6.pdf

(11) https://www.sitra.fi/sv/cases/skolornas-matsvinn-till-invanarstugor-och-arbetslosa/

(12) https://www.sitra.fi/sv/cases/avloppsvattnens-fosfor-foradlas/

(13) http://www.ks.no/fagomrader/samfunn-og-demokrati/samferdsel-plan-og-miljo/sirkular-okonomi/gode-eksempler/samarbeid-med-utdanningssektoren/

(14) http://www.ks.no/fagomrader/samfunn-og-demokrati/samferdsel-plan-og-miljo/sirkular-okonomi/gode-eksempler/strategiske-samarbeid---sesammen/

(15) https://nyheder.randers.dk/alle-nyheder/2017/1/ny-virksomhed-styrker-genbrug-og-giver-flere-rummelige-arbejdspladser/ 
Tabel 2: Byggeri og anlæg

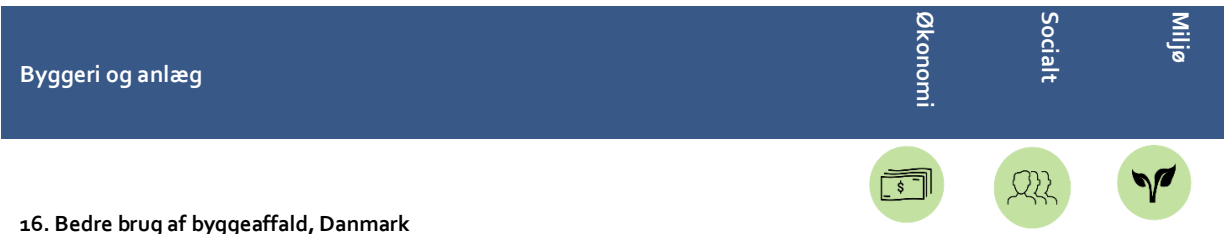

16. Bedre brug af byggeaffald, Danmark

I Danmark er Vejle Kommune i gang med et projekt kaldet "Bedre Brug af Byggeaffald", som skal sikre, at mere byggeaffald bliver genanvendt. Idéen er, at forskellige aktører og interessenter, såsom arkitekter, bygherrer og nedrivere, der ikke normalt samarbejder direkte om byggeaffald, skal bruge hinandens kompetencer. Målet med at aktørerne udnytter hinandens kompetencer er, at udvikle bæredygtige og miljøvenlige koncepter af affald fra byggerier og anlæg i byer med over 30.000 indbyggere. Aktørerne skal udvikle smartere metoder og mere intelligente løsninger til at fremme genbrugsøkonomien indenfor byggeaffald. Projektet udvikles i samarbejde med Kolding Kommune. Læs mere om projektet Bedre brug af byggeaffald via link (18).

17. Genanvendelse af byggematerialer fra nedrevet skole, Danmark

Holbæk Kommune i Danmark har opnået besparelser ved at fokusere på ressourceudnyttelsen ved nedrivning af Brunhøjskolen, en nedslidt bygning fra 1971. En grundig forundersøgelse og et tæt samarbejde mellem Holbæk Kommune, NIRAS og Søndergaard Nedrivning A/S har medvirket til, at der er opnået en genbrugs- og genanvendelsesprocent på 97,5 procent.

Læs mere om projektet Genanvendelse af bygningsmaterialer via link (17).

18. Genbyg Skive - Sortering, behandling og genanvendelse af byggeaffald, Danmark

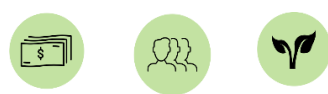

Skive Kommune i Danmark har iværksat projektet Genbyg Skive med det formål at skabe nye erhvervsmuligheder inden for genbrug af byggeaffald. I samarbejde med Gamle Mursten ApS, Troldtekt A/S og Tom Probansky bliver materialerne fra de ca. 150 huse, som årligt nedrives i Skive, sorteret, behandlet og genanvendt. Et samarbejde med Erhvervsakademiet Dania har desuden resulteret $\mathrm{i}$ udvikling af nye forretningsmodeller til behandling og genbrug af byggeaffald, som har dannet en ny erhvervsklynge med nye arbejdspladser i Skive Kommune. Læs mere om projektet Genbyg Skive via link (18).

19. "Hyllie" - En klimavenlig bydel, Sverige

Hyllie er Malmøs største byudviklingsområde med målet om at bygge en cirkulær bydel. Kommunen har foretaget et omfattende tiltag for at sikre ressourceeffektive strukturer for transport, energi og jord. Malmø har indledt en fælles proces med E.ON Sweden og vand- og affaldsvirksomheden VA SYD. Målet er at udvikle Hyllie til et forbillede i Øresundsregionen som den mest bæredygtige bydel. Der fokuseres på, at beboerne i Hyllie skal motiveres til at forbruge ansvarligt ved at lade dem forstå deres energibehov og kontrollere deres forbrug. E.ON har udviklet en app, som eksempelvis hjælper beboerne med at sætte temperaturen i huset til at tilpasse sig i løbet af dagen, eller at sætte vaskemaskinen til at køre, når efterspørgslen på energi er lav. En Smart Grid-løsning betyder desuden, at Hyllie består af et integreret produktions- og distributionssystem i form af eksempelvis tag med solpaneler og kældre med reaktive opvarmningssystemer, samt VA SYD's hjælp med produktion af biogas ved udnyttelsen af organisk affald. Læs mere om udviklingsprojektet for Hyllie på eureka.eu.com via link (19).

20. "Kilen" - En Cradle-to-Cradle bydel, Sverige

Ronneby Kommune i Sverige har startet et byprojekt inspirereret af Cradle-to-Cradle-konceptet, som er et innovationsplatform for at maksimere økonomiske, økologiske og sociale fordele. Målet er, at byområdet "Kilen" skal fornys i overensstemmelse med cirkulære økonomi-principper. Kommunen har tilkaldt arkitekter, ingeniører og andre eksperter med fokus på bæredygtighed til at indgå samarbejde med kommunen om denne områdefornyelse. Visionen er et byområde, der inspirerer, giver et positivt indtryk på miljøet, bidrager til menneskers sundhed og bliver et mødested for alle. Læs mere om udviklingsprojektet for Kilen på ronneby.se//kilen via link (20). Læs om kommunes Generelle kvalitetsprogram inspireret af $\mathrm{C}_{2} \mathrm{C}$, hvori det er angivet, hvilke værdier Kilen skal indeholde.via link (20.1). 


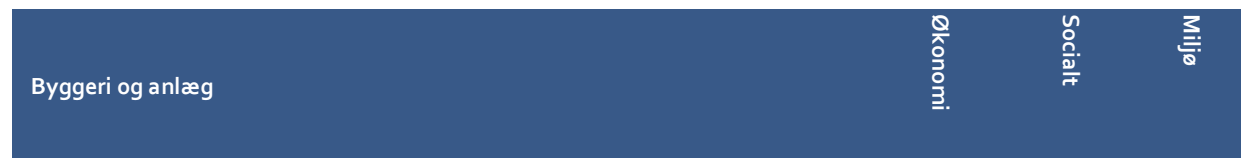

21. Multifunktionelt rådhus, Danmark

I Skanderborg Kommune i Danmark er der blevet bygget et rådhus som integrerer kommune, politi, idræts- og kulturcenter i én og samme bygning. Det er en ny og fleksibel måde at udnytte kvadratmeterne på, som både skaber mulighed for innovation, samarbejde og sundhed. Denne måde at udnytte kvadratmeterne på giver økonomiske og ressourcemæssige fordele. Driften på Rådhuset betyder, at der opnås en jævn og bedre udnyttelse af solenergien, ved at bygningen anvendes i alle dagtimer. Af energibesparende og effektiviserende initiativer kan nævnes, at der ikke er varmt vand i hanen på håndvasken, at iRobotter sørger for basal rengøring, og at der automatisk slukkes for lyset om natten. Det betyder, at det nye rådhus giver en årlig driftsbesparelse på 12 mio DKK. Læs mere om Skanderborg Rådhus via link (21).

22. Skolebyggeri af gamle mursten fra hospital, Danmark

Københavns Kommune i Danmark har i samarbejde med virksomheden Gamle Mursten ApS fået udsorteret, renset og genbrugt 140.000 mursten fra nedrivningen af en ældre bygning på Bispebjerg Hospital til brug ved opbygning af Katrinedalskolen i Vanløse. Københavns Kommune opnår økonomiske besparelser ved genbrug af mursten, og på samme tid spares klimaet for $0,5 \mathrm{~kg}$. $\mathrm{CO}_{2}$ pr. enkelt ny mursten. Læs mere om projektet Skolebyggeri af gamle mursten fra hospital via link (22).

Note: (16) https://www.vejle.dk/om-kommunen/udvikling-med-vilje/vi-udvikler-byerne/projekt-bedre-brug-af-byggeaffald/

(17) https://www.niras.dk/projekter/genanvendelse-af-bygningsmaterialer/

(18) http://rethinkbusiness.dk/wp-content/uploads/sites/2/2016/07/rethink-business-case-skive-kommunes-final11-03-2015.pdf

(19) https://eureka.eu.com/innovation/circular-economy-malmo/

(20) https://www.ronneby.se/bygga-bo--miljo/byggprojekt/kilen---en-ny-stadsdel.html

(20.1) https://www.ronneby.se/download/18.346abbe115bc381a8fbcgac/1493726177436/Generelltprocent2okvalitetsprogramprocent2ofprocent $C_{3}$ procentB6rprocent2oplaneringprocent20ochprocent2obyggandepro-

cent2oiprocent2oRonneby_versionprocent202.pdf

(21) http://www.ktc.dk/artikel/skanderborg-raadhus

(22) http://www.dagensbyggeri.dk/artikel/89332-skolebyggeri-af-gamle-mursten-fra-hospital 
23. Fra rest til ressource - Udvikling af grønne forretningsmodeller, Danmark

I projektet "Fra Rest til Ressource" har de danske kommuner Holbæk, Slagelse, Odsherred, Køge, Kalundborg og Guldborgsund fra 2014-2017 tilbudt virksomheder en gennemgang af deres ressourceanvendelse og på baggrund af dette ressourcetjek, at få udviklet en nye og grønnere forretningsmodel. Projektet er drevet af Dansk Symbiosecenter med Danmarks Tekniske Universitet som partner.

Virksomhederne har fået rådgivning om mere effektiv ressourceanvendelse, og om hvordan dette medvirker til at reducere driftsomkostningerne i virksomheden, reducerer virksomhedens $\mathrm{CO}_{2}$-udslip og øge konkurrenceevnen. I projektet forventes energibesparelser på ca. $33.000 \mathrm{GJ} / a ̊ r$, materialebesparelse på ca. 1 ton/år og en $\mathrm{CO}_{2}$-reduktion på ca. 14.000 $\mathrm{CO}_{2} /$ år. Læs mere om projektet Rest til Ressource via link (23). Læs mere om resultaterne i projektet fra virksomheden selv via link (23.1).

24. Reducering af forkastet tøj og tekstil, Norge

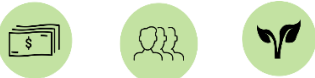

I Asker Kommune i Norge blev der i 2017 smidt cirka 325 tons brugbare tekstiler ud, der som kommunen skriver "kunne være kommet noen til gode". Derfor har kommunen opsat containere for indsamling af tekstiler til genbrug, som går til virksomhederne Fretex og UFF Norge. Virksomhederne er socialøkonomiske med fokus på inddragelse af socialt udsatte i deres arbejde, på forbedring af miljøet og på humanitære indsatser. De tekstiler som er for ødelagte til at blive solgt $\mathrm{i}$ en genbrugsbutik bliver eksempelvis redesignet til tasker eller klude.

Læs mere om kommunes indsats her via link (24).

25. Industriklynger - Et symbiostisk samarbejde, Norge

Industriklyngen i MO i Norge er et eksempel, hvor der er opstået et tæt samarbejde mellem private og industrielle aktø rer. Formålet med industriklyngen er, at virksomhederne kan udnytte hinandens restprodukter. Eksempelvis udnyttes overskudsenergi mellem virksomhederne, hvilket fører til en betydelig reducering i energiforbruget. Industriklynger er en vigtig udviklingsmulighed for kommunernes arbejde med cirkulær økonomi.

Læs mere om industriklyngen ks.no/naringsklynger via link (25).

26. Kompostbare tryksager, Danmark

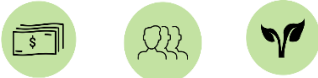

De danske kommuner: Lejre, Gladsaxe, Hvidovre, Rødovre og København kommuner har indgået samarbejder med trykkerifirmaet KLS PurePrint i forbindelse med bæredygtig tryk af materiale til mindre udbud, magasiner, foldere mm. I en trykkeribranche som ellers er presset af den digitale udvikling, blev et nyt, innovativt, grønt produkt et vendepunkt for trykkeriet.

I dag er virksomheden i vækst og ser nye markeder for bæredygtige trykte emballager (også udlands). Trykkeriet KLS har som en ud af to virksomheder i verden udviklet 100 procent giftfrie og 100 procent biologisk nedbrydelige tryksager og emballage - med en Cradle-to-Cradle certificering. Udviklingsarbejdet blev igangsat tilbage i 2007 og med udgangspunkt i FN's klimarapport, blev der lagt en strategi om at gøre tanke til handling og dermed blive Skandinaviens grønneste trykkeri. Læs mere om KLS PurePrints på https://klspureprint.dk via link (26).

27. Netværk for bæredygtig erhvervsudvikling (NBE-N), Danmark

NBE-NordDanmark er et samarbejde mellem Aalborg Kommune, Hjørring Kommune, Business Aalborg, Hjørring Erhvervscenter, Aalborg Universitet, Eniig Energi A/S, samt alle nordjyske kommuner og virksomheder som fremmer en bæredygtig udvikling gennem deres medlemskab af netværket. Målet om at fremme et bæredygtigt energi- og ressourceforbrug i kommunerne og virksomhederne støttes ved konkrete tilbud og projekter, som består af:

- En screening af virksomheden, som kan give et overblik over ressourceeffektive løsninger, samt hvilke andre lokale virksomheder de potentielt kan indgå en symbiose med.

- $\quad$ En plan for bæredygtig forretningsudvikling (PBF), som er et strategisk ledelsesværktøj skræddersyet til den enkelte virksomhed, der ønsker at medvirke i et udviklingsforløb med fokus på bæredygtig omstilling. Netværksaktiviteter, der efter virksomhedens ønsker, kan omhandle forskellige temaer.

Læs mere om nbe- $n$ og deres case-samling over konkrete cases med medlemskommuner: nben.dk/cases via link (27). 


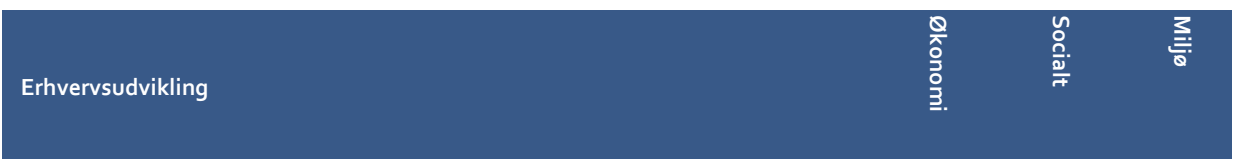

28. Recirkulering af fiskeri- og opdrætudstyr, Norge

Nofir er en virksomhed stiftet i 2008 i samarbejde med Nordland fylkekommune og private aktører. Formålet med Nofir er at etablere et landsomfattende system for indsamling af kasseret fiskemateriale, da omkring 15.000 tons redskaber og udstyr fra fiskeri og opdræt årligt bliver kasseret i Norge. I stedet kan nylon fra gammelt fiskeriudstyr blandt andet blive til produktionen af sokker, tæpper og badetøj. Nofir fik 2012 bevilliget støtte fra EU til at videreføre den norske ordning, og har siden da også samlet materiale ind fra dele af Europa.

Læs mere om Nofir. Læs mere om samarbejdet ks.no/resirkulert-nylon via link (28).

29. Ressource city - Cirkulær industriklynge, Danmark

Ressource City er et by-strategisk udviklingsprojekt i Næstved Kommune i Danmark, der skal skabe produktion og arbejdspladser med afsæt i lokale ressourcer i området. Ressource City er en grøn industriklynge bestående af virksomheder, iværksættere og uddannelsesinstitutioner med fokus på upcycling. Ressource City er et bredt samarbejde mellem Næstved Erhverv, Arkitektskolen, DTU, FORCE, Lendager Arkitekter og Maglemølle Erhvervspark A/S. Projektet har til formål at rådgive om indsamling, sortering og genanvendelse af affaldsprodukter, med øje for udvikling af produkter af materiale, som andre virksomheder eller institutioner betragter som affald. Projektet fremmer således energi- og effektiviseringsudnyttelse af materialer, som skaber grøn vækst i Næstved.

Læs mere om netværket og projektet Ressource City via link (29).

30. Udviklingssamarbejde om genanvendeligt emballage, Norge

ROAF (Romerike avfallsforedling IKS) er et kommunalt affaldsselskab i Norge, som oplever, at producenter efterspørger, hvordan de kan udvikle genanvendeligt emballage til deres produkter. Dette har resulteret i, at ROAF har meldt sig ind i Producentforeningen (en emballageforening), hvilket bidrager til øget dialog mellem affaldsbranchen og producenterne. Målet med samarbejde og dialog er at øge kompetencerne til at udvikle emballage, der får madvarer til at holde længere, og som kan indgå i nye værdikæder.

Læs mere om samarbejdet ks.no/deltakelse-i-produsentforeningen via link (30).

Note: (23) https://symbiosecenter.dk/project/rest-til-ressource/

(23.1) http://publikationer.regionsjaelland.dk/Ajour/ajour-maj-2017/?page=1

(24) https://www.asker.kommune.no/avfall-og-gjenvinning/yggeset-avfallspark/ombruk-av-tekstiler/

(25) http://www.ks.no/fagomrader/samfunn-og-demokrati/samferdsel-plan-og-miljo/sirkular-okonomi/gode-eksempler/naringsklynger/

(26) https://klspureprint.dk/

(27) https://nben.dk/om-nbe

(27.1) https://nben.dk/cases

(28) https://nofir.no/no/

(28.1) http://www.ks.no/fagomrader/samfunn-og-demokrati/samferdsel-plan-og-miljo/sirkular-okonomi/godeeksempler/resirkulert-nylon/

(29) https://ressourcecity.dk/

(30) http://www.ks.no/fagomrader/samfunn-og-demokrati/samferdsel-plan-og-miljo/sirkular-okonomi/gode-eksempler/deltakelse-i-produsentforeningen/ 


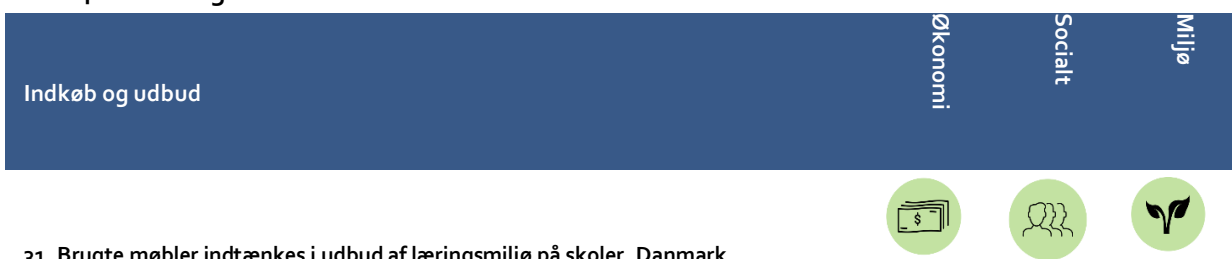

31. Brugte møbler indtænkes i udbud af læringsmiljø på skoler, Danmark

De fleste kommuner kasserer gamle skolemøbler og erstatter dem med nye, når de skal skiftes ud. Aalborg Kommune Danmark har udformet et udbud, hvor de gamle møbler genanvendes, repareres og tænkes ind i nye læringsmiljøer på skoler. Det er relativt nyt i Danmark at tænke cirkulær økonomi ind i et offentligt udbud. Kommunen har indledt et samarbejde med en lang række aktører: Aalborg Universitet, Netværk for Bæredygtig Erhvervsudvikling NordDanmark, Aalborgs skoler, Det Grønne Rejsehold og Miljøministeriets rejsehold for Grønne Indkøb. Aktørernes fokus har været, at ressourcerne fra de gamle læringsmiljøer skal genanvendes, uden at det går ud over kvaliteten. Udbuddet har således krævet samarbejde på tværs for at skabe innovative løsninger inden for offentlige indkøb. Der er fire skoler med i projektet: Stolpedalsskolen, Vestbjerg Skole, Vester Hassing Skole og Herningvej Skole. Højer Møbler A/S vandt udbuddet. Læs mere om projektet på centerforgrønomstilling.dk via link (31).

32. Byttecentral på genbrugspladser, Danmark

Aarhus Kommune, i Danmark, har etableret genbrugspladsen REUSE i Aarhus by, hvor borgere har mulighed for at tage aflagte ting og sager med hjem gratis. REUSE er en byttecentral, der skal fremme direkte genbrug mellem borgerne. Både kommunen og borgerne kan aflevere brugte ting, der har chancen for et nyt liv i stedet for at det bortskaffes som affald. Desuden tilbyder Aarhus Kommune en gratis storskraldsordning til borgerne, så det bliver lettere at få indleveret større sager til REUSE.

Læs mere om REUSE via link (32).

33. Genbrug af kontormøbler, Danmark

Aarhus- og Hedensted Kommune i Danmark er blandt flere kommuner, som køber brugte kontormøbler af virksomheden 3 R Kontor. 3R Kontor opkøber, istandsætter og sælger brugte kontormøbler som el-hæve-sænke borde, kontorstole og andre konferencemøbler. Kommunerne sparer 6o-70 procent i forhold til nypriserne ved at købe kontormøbler gennem $3 R$ Kontor og skåner samtidig miljøet, ved at møblerne ikke ender som affald.

Læs mere om 3R Kontor 3xr.dk via link (33).

34. Genbrugsparken "Alelyckan", Sverige

Alelyckan er en velorganiseret affalds- og genbrugsstation i Sverige ejet af Göteborg Kommune. Hos Alelyckan kan borgere både bortskaffe og købe brugte materialer af forskellig art. Borgere får hjælp til at sortere deres brugte materialer, og personalet sørger for at sende materialerne derhen, hvor de hører til.

Der findes tre forskellige salgssteder i Alelyckan: Återbruket, Stadsmissionen og Returhuset. Återbruket sælger byggemateriale og Stadsmissionen sælger tøj, sko osv. Returhuset er multifunktionelt, ved at der renoveres (især) cykler og andre brugte og ødelagte produkter, som derefter sælges videre. Returhuset har en økologisk cafe, og der anvendes bioaffald i deres bagvedliggende frugthave. Overskuddet fra salget i de tre butikker går til økonomisk trængende borgere. Læs mere om genbrugsparken Alelyckan via link (34).

35. Indkøb af bæredygtig arbejdsbeklædning, Danmark

Odense Kommune i Danmark har indgået samarbejde med De Forenede Dampvaskerier med henblik på, at produktionen og bortskaffelsen af arbejdsbeklædningen til kommunens 2200 sundhedsfaglige personale er bæredygtigt. De Forenede Dampvaskerier afhenter, vasker, tørrer, pakker og tilbagelevere til kommunens institutioner. Tøjet indeholder ikke miljøbelastende stoffer og ressourceforbruget mindskes alene ved at kommunen har et smallere sortiment med fokus på at reducere spild. Det bæredygtige arbejdstøj giver Odense Kommune en besparelse på 1,5 mio. DKK. årligt. Læs mere om projektet Bæredygtigt arbejdstøj til plejepersonalet i Odense Kommune via linket (35). Odense Kommune er nomineret til Grøn Indkøbspris Grøn Indkøbspris 2016 (link [35.1]). 


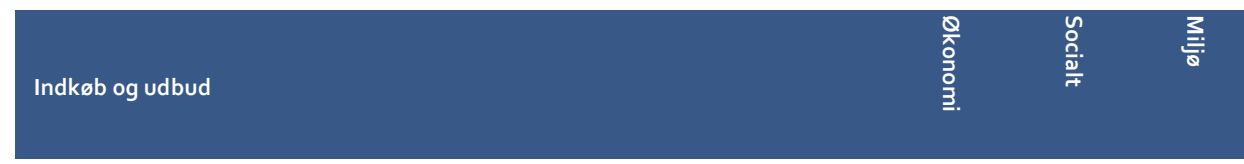

36. IT-udstyr recirkuleres, Danmark

Sønderborg Kommune i Danmark er én ud af flere kommuner, som samarbejder med IT-virksomheden Refurb. Refurbs opkøber udtjent IT-udstyr fra både private og offentlige virksomheder for derefter at istandsætte, dataslette og opdatere det med nyeste software. Sønderborg Kommune sparer både klimaet for $\mathrm{CO}_{2}$ og opnår økonomisk gevinst, da de slipper for at betale for at komme af med det udtjente IT-udstyr. Omkring 95-97 procent af det udtjente IT-udstyr kommer tilbage til markedet som genbrugt IT, i stedet for at det ender som direkte affald. Læs mere om Refurb refurb.dk, læs mere om projektet her via link (36)

37. Kommunal Möbelcirkeln - Genbrug af brugte møbler, Sverige

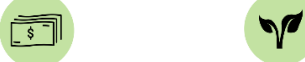

Indkøb af nye møbler kan være en betydelig udgiftspost for en kommune. I 2016 købte Växjö Kommune i Sverige møbler for 19 millioner. Med Möbelcirkeln forventer Växjö Kommune at spare både penge og skåne miljøet.

Möbelcirkeln er et koncept udarbejdet af kommunen, hvor kommunale myndigheder og virksomheder kan indlevere brugte møbler til et lager, hvor møblerne bliver repareret og istandsat inden de bliver lagt op på en online platform. Herigennem kan kommunens forvaltninger købe de tilgængelige møbler ved kun at betale for transportomkostningerne. Læs mere om projektet på vxonews.se via link (37).

38. Off2Off - Online delingsportal til salg og køb af brugte møbler, Sverige
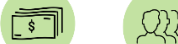

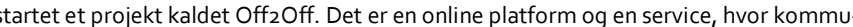
nens mange institutioner kan lægge billeder ud af brugte møbler, som de ikke ønsker at bruge længere. Kommunens ansatte får adgang til portalen og kan overtage de brugte møbler mod betaling for transport og håndtering Kommunen har et ønske om at udvide konceptet både indholdsmæssigt og geografisk, her tænkes der konkret på nabokommunerne Trelleborg og Skurup. Målet er at skabe en divisionstjeneste, der strækker sig over de kommunale grænser og ikke kun fokuserer på objekter, men også tjenester. Det skal blive en model, der kan bruges af mindre kommuner, der ønsker at samarbejde om alt fra genanvendelse til udveksling af tjenester på forskellige områder, da alle kommuner muligvis ikke har de samme egenskaber. Læs mere om projektet Off2Off på ystad.off2off.se via link (38). Læs mere om projektet i Ystad på s. 20 i udgivelsen "Kommunerna visar vägen för mindre avfall" på avfallsverige.se.pdf via link (38.1)

39. PlusButikken - Direkte genbrug, Danmark

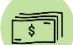

AffaldPlus vil via genbrugsbutikken PlusButikken, som er beliggende i Næstved i Danmark, sætte en stopper for, at de fleste af de materialer og ting, som indleveres på deres genbrugspladser, ender som affald. De genbrugelige materialer og ting sorteres fra og sættes til salg i PlusButikken. Ligeledes kan private personer også selv sætte sine genbrugelige ting til salg i PlusButikken. Direkte genbrug via PlusButikken betyder færre omkostninger på affaldsbehandling og en reducering af ressourceforbruget i form af råstoffer og energi til produktion af nye varer, hvilket mindsker $\mathrm{CO}_{2}$-udslippet. Læs mere om PlusButikken via link (39). Læs mere om direkte genbrug hos AffaldPlus via link (39.1).

40. ReTuna - Et cirkulært shoppingcenter, Sverige

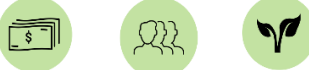

ReTuna er ejet af Eskilstuna Kommune i Sverige, som er det første genbrugsshoppingcenter i verden. I shoppingcenteret findes flere forskellige butikker som alle sælger brugte genstande, der er blevet repareret eller brugt i en ny konstellation. Storcenteret ligger ved siden af ReTuna Genbrugscentral, hvor borgere kan aflevere brugte genstande. Personalet på genbrugscentralen sorterer sagerne efter, hvorvidt de kan sælges videre i shoppingcenteret. Personalet i shoppingcenterets butikker bestemmer selv over produkterne, eksempelvis om de skal repareres eller omskabes før det sælges videre. ReTuna arrangerer også oplæg, workshops mv. med fokus på bæredygtighed. Endvidere samarbejder de med den lokale folkehøjskole, som har udarbejdet et undervisningsprogram om bæredygtighed. Læs mere om projektet på www.retuna.se via link (40).

Note: (31) http://www.centerforgrønomstilling.dk/nyheder/danmarks-bedste-udbud

(32) https://affaldvarme.aarhus.dk/affald-og-genbrug/genbrugsstationer/reuse/

(33) https://www.3xr.dk/shop/profile.html

(34) ||klo1s1oglpriv\$|mvsc/default.aspx

(35) https://www.odense.dk/presse/pressemeddelelser/pressemeddelelser-2015/baeredygtigt-arbejdstoej-til-

plejepersonalet-i-odense-kommune

(35.1) https://www.odense.dk/presse/pressemeddelelser/pressemeddelelser-2016/nyt-og-baeredygtigt-jobtoej-

er-nomineret-til-groen-indkoebspris-2016

(36) https://www.refurb.dk/refurb-og-miljo 
(36.1) https://www.refurb.dk/blog/soenderborg-kommune-tjener-paa-kasserede-computere-og-hjaelpermiljoeet/index.html

(37) http://www.vxonews.se/article/vaxjo-kommun-infor-miljosmart-mobelhantering/

(38) http://ystad.off2off.se/procent23!/pages/om

(38.1) https://www.avfallsverige.se/fileadmin/user_upload/Nyheter/Bilaga_Dagens_Samhalle_180607.pdf (39) https://www.affaldplus.dk/node/313

(39.1) https://www.affaldplus.dk/node/180

(40) https://www.retuna.se/sidor/in-english/ 


\section{Litteraturliste}

Baver, Bjørn og Bode, Ida (2008): Kvalitetsledelse På Natur og Miljøområdet - Opsamling af erfaringer fra en række kommuners indledende arbejde med kvalitetsstyring i henhold til kvalitetsstyringsloven.

Baver, Bjørn et al (2005): IMPEL - Ledelseshåndbog for miljøadministrationer, Orientering fra Miljøstyrelsen · Nr. 22005

Circle Economy, TNO, FABRIC: CIRCULAR AMSTERDAM - A vision and action agenda for the city and metropolitan area.

COM (2018): Meddelelse fra Kommissionen til Europa-parlamentet, Rådet, Det europæiske økonomiske og sociale udvalg og regionsudvalget - om en overvågningsramme for den cirkulære økonomi \{SWD(2018) 17 final\} Strasbourg, den 16.1.2018 https://eur-lex.europa.eu/LexUriServ/LexUriServ.do?uri=COM:2018:0029:FIN:DA:PDF

CRI (2015): Moving towards a circular economy - successful Nordic business models, Policy Brief, Nordisk Ministerråd.

Europa Kommissionen (2018): EU's tilgang til bæredygtig udvikling. EU's og medlemslandenes tilgang til gennemførelsen af FN's 2030-dagsorden for bæredygtig udvikling: https://ec.europa.eu/info/strategy/international-strategies/global-topics/sustainable-developmentgoals/eu-approach-sustainable-development_da

EU's arbejde med cirkulær økonomi: http://ec.europa.eu/environment/circular-economy/index_en.htm

Forum for bæredygtige indkøb (2017): Cirkulær Indkøbsguide. Udarbejdet af temagruppen om "Cirkulære Indkøb 2016-2017" under Forum for Bæredygtige Indkøb.

Herning Kommune: Vejledning i implementering af cirkulær økonomi i offentlige indkøbsaftaler. http://www.oneplanetnetwork.org/sites/default/files/vejledning_i_implementering_af_cirkulaer_okonomi_i_offentlige_indkobsaftaler.pdf

Kommunernes Landsforening (2016): Den cirkulære kommune - Case- og eksempelsamling. https://www.kl.dk/media/7954/case-og-eksempelsamling-den-cirkulaere-kommune-kl2017.pdf

Kommunernes Landsforening (2016): Den cirkulære kommune - Inspirationskatalog: https://www.kl.dk/media/7955/inspirationskatalog-den-cirkulaere-kommune-kl-april-2017.pdf

Nordregio (2016): An actor-oriented survey of territorial governance systems in the Nordic capital regions, by Peter Schmitt, Lisbeth Greve Harbo, Veera Lehto, Nordregio Working Paper 2011:6

Nordregio and the authors (2017): White Paper on Nordic Sustainable Cities. Borges, L. A.; Nilsson, K.; Tunström, M.; Dis, A. T.; Perjo, L.; Berlina, A.; Costa, S. O.; Fredricsson, C.; Grunfelder, J.; Johnsen, I.; Kristensen, I.; Randall, L.; Smas, L.; Weber, R. (2017):

http://www.nordregio.se/nordicsustainablecities

PwC (2018): Circular Economy in Cities Evolving the model for a sustainable urban future, World Economic Forum, White Paper.

Sitra (2016): Leading the cycle - Finnish road map to a circular economy 2016-2025. Sitra Studies 121

Sveriges Kommuner och Landsting (2017): Miljöarbetet 2017 i landsting och regioner 


\section{Summary}

Circular economy in the municipality centers around a cycle-based green transition across administrations and in all activities is the municipality. Through planning, the regulatory tasks, purchase, supply and business promotion, the municipality can accelerate the circular transition in its services to the citizens and in industry. This guide summarizes and conveys experiences and methods on circular initiatives from across the Nordic countries with the aim to make the circular efforts in Nordic municipalities more dynamic and effectual.

The Nordic municipal associations support circular economy in the municipalities through dialogue, exchanges of knowledge and networking activities. Furthermore, cooperation between the municipal associations and the state authorities is taking place in alle the Nordic countries. In this respect, Finland has proven itself as a leading example with an especially organized and formalized collaboration.

There is great variation between the municipalities in terms of how far each of them have come in transitioning to a more circular framework. From small concrete projects to grand trans-municipal visions there are numerous examples of circular initiatives generating rewards in all three dimensions of sustainability: Environmentally, economically and socially. The review of the efforts surrounding circular economy in the Nordic municipalities indicates that innovative activities are especially present in four areas of administration:

- Resources and provision

- Business development

- Purchase and supply

- Building and installation

The four themes above and the three sustainability dimensions are all equally legitimate, as the line of approach depends on the specific municipal context - although, the environmental dimension is naturally present in all cases. The economic dimension is most noticeable in the themes of business development and purchase and supply, denoted as increased revenue, new markets and saved expenses. The social dimension understood as social-economic jobs, co-creation, citizen involvement etc. - is also clearly visible in the examined cases with educational activities, locally accessible environmental projects and social-economic jobs in the waste industry.

In many cases, the municipalities act as both the initiators and drivers of the circular efforts, as they are able to endure a short-term cost in order to secure improved environmental conditions and lowered cost for their citizens in the long run. To name an 
example, this is true for the development of new business models in areas of waste and wastewater, which in turn creates circular jobs in the municipality.

The survey of the Nordic municipalities' efforts to promote circular economy is based in an organizational framework, which has deepened the understanding of how the municipal and organizational structure enables the development and implementation of new circular projects. The importance of the different elements varies between the municipalities, and efforts in each of the organizational elements can further the gradual transition to circular economy. However, for circular economy to become deeply rooted and fully realized in the municipalities, all the organizational elements must come into play:

- A general vision for circular economy in the municipality and clear leadership both politically and administratively;

- A strategy for circular economy in the municipality and a distinct plan for the project in question;

- Employees that are equipped with the right qualifications for the effort, and a clear sense of commitment and ownership shared by employees and stakeholders;

- A municipal culture and structure that underpin both the overall effort and the specific projects;

- Well-functioning systems to support circular economy projects;

- Means and channels for effective communication;

- Agreements on broad and positive partnerships to follow through with the efforts. 
Nordisk Ministerråd

Nordens Hus

Ved Stranden 18

1061 København

www.norden.org

\section{Cirkulær guide}

Cirkulær økonomi i kommunen handler om en kredsløbsfokuseret grøn omstilling på tværs af forvaltninger og i alle kommunens aktiviteter.

Igennem planlægning, myndighedsopgaver, indkøb, udbud og

erhvervsfremmeindsatser kan kommunen accelerere den cirkulære omstilling

i erhvervslivet og i services til borgerne. Denne vejledning opsamler og

formidler erfaringer og metoder på cirkulære initiativer fra kommuner over hele Norden, så indsatsen kan blive endnu mere dynamisk og effektfuld. 